\title{
Measuring performance differentials across entrepreneurship types
}

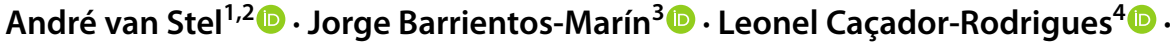 \\ Ana Millán ${ }^{5}$ ( ) José María Millán ${ }^{6,7}(\mathbb{C}$
}

Accepted: 1 May 2021

(c) The Author(s), under exclusive licence to Springer Science+Business Media, LLC, part of Springer Nature 2021

\begin{abstract}
It is increasingly being recognized that different types of entrepreneurs exist with different performance levels and different contributions to the economy. Two common classifications of entrepreneurship types are based on professional status and start-up motive, where independent own-account workers are assumed to perform better than dependent self-employed and opportunity entrepreneurs are assumed to perform better than necessity entrepreneurs. However, these supposed performance differentials are seldomly tested or quantified. Using recent data drawn from the European Working Conditions Survey for the EU-28, we explore self-employment earnings (as an indicator of performance) across these different entrepreneurship types. Our results from OLS and multilevel linear regressions show that dependent self-employed workers are indeed observed to have significantly lower earnings than independent own-account workers, but the difference is only $10 \%$, suggesting that the precarious nature of the dependent self-employed may be overstated in certain policy circles. Regarding start-up motive, our paper highlights the importance of distinguishing the group of entrepreneurs who simultaneously have both opportunity and necessity motives to start a business.
\end{abstract}

Keywords Earnings · Types of entrepreneurship - Self-employment · Performance · European working conditions survey

JEL classifications D31 $\cdot \mathrm{J} 24 \cdot \mathrm{L} 25 \cdot \mathrm{L} 26 \cdot \mathrm{O} 52$

\section{Introduction}

There is a near consensus among academics and policymakers on the importance of entrepreneurship as a driving force of economic development (Fritsch, 2013). Thus, entrepreneurs substantially contribute to job creation, generate and disseminate

José María Millán

jmillan@uhu.es

Extended author information available on the last page of the article 
innovative ideas, increase competition and enhance economic efficiency and productivity (Acs, 2006; Audretsch \& Thurik, 2004). However, it is also increasingly being recognised that not all entrepreneurs are the same and some types of entrepreneurs contribute substantially more to the economy than other types (Baumol, 1990; Urbano et al., 2020). In this regard, many theoretical arguments are provided in the literature as to which types are more productive and which types are less productive (Wennekers \& Van Stel, 2017). For instance, as innovation spurs firms' and workers' productivity levels, it is clear that innovative entrepreneurs contribute more to the economy that non-innovating entrepreneurs. Similarly, entrepreneurs running a fastgrowing business contribute more than entrepreneurs without an ambition to grow (Henrekson \& Johansson, 2010). However, even though in the above examples the link between entrepreneurship types and their relative contributions to the economy is quite clear, this is not always the case for other categorizations of entrepreneurship types where performance differentials across different types of entrepreneurs are often simply assumed to exist but are seldomly quantified.

The purpose of this paper is to identify entrepreneurship types along two commonly used dimensions — professional status and start-up motive — and to test, rather than assume, whether certain types indeed perform better than others. Moreover, we aim to measure the size of the performance differentials between different groups. Concretely, regarding professional status we distinguish between self-employed with employees, independent own-account workers, and dependent self-employed workers (Carrasco, 1999; Burchell et al., 1999), while regarding start-up motive we distinguish between opportunity-driven, necessity-driven, and hybrid opportunity-necessity entrepreneurs (Reynolds et al., 2002; Block \& Wagner, 2010; Kautonen \& Palmroos, 2010). ${ }^{1}$ Hence, our research question is: Are there structural performance differences between entrepreneurship types, and if so, which types perform better than others? We investigate this question by using recent data drawn from the European Working Conditions Survey for the EU-28, and by exploring self-employment earnings (as an indicator of performance) across these different entrepreneurship types. In our regression models explaining performance, we include a whole range of control variables so that the role of entrepreneurship types is isolated as accurately as possible.

The remainder of the paper is structured as follows. In second section we provide a literature review and derive hypotheses regarding the relative performance of the different types of self-employment. The database and the variables that we employ from it are discussed in the third section. In the fourth section describes our methods of analysis while the fitfh section describes the empirical results. Finally, the sixth section concludes.

\section{Literature review and hypotheses}

As mentioned earlier, in this paper we identify entrepreneurship types along the dimensions of professional status and start-up motive, and empirically test for performance differences between different types. In the present section we

\footnotetext{
1 The definitions of these entrepreneurship types will be discussed in the next section.
} 
will therefore first discuss extant literature on the entrepreneurship types that we focus on in this paper, while identifying gaps in the literature that the current paper aims to fill ("Identifying entrepreneurship types based on professional status and start-up motive" section). We then derive hypotheses as to which types are expected to have higher or lower entreprenerial performance ("Hypotheses" section).

\section{Identifying entrepreneurship types based on professional status and start-up motive}

The first dimension along which we identify entrepreneurship types is professional status, leading to three types: self-employed with employees, independent own-account workers, and dependent self-employed workers. The term dependent self-employment refers to those workers in the grey zone between employment and self-employment, i.e., those outsourced workers who are economically dependent on (and often hierarchically subordinate to) the firms with which they contract (Dennis, 1996; Burchell et al., 1999; Muehlberger, 2007; Böheim \& Muehlberger, 2009; Román et al., 2011; Quinlan, 2012; Stewart \& Stanford, 2017; Williams \& Horodnic, 2019).

Despite the increasing attention for this group of workers, a conditional analysis on how dependent self-employed workers compare to other types of entrepreneurs in terms of performance does not exist to date, to our knowledge. Thus, even though the phenomenon of dependent self-employment is often seen as a worrisome development in modern labor markets (Eichhorst et al., 2013; ILO, 2006), studies that quantify performance differentials with other types of entrepreneurs - in particular independent own-account workers - are lacking. ${ }^{2} \mathrm{We}$ contribute to extant literature by quantifying such performance differentials. While doing so, we follow the recommendation of Cieślik and Dvouletý (2019) to identify dependent self-employed workers on the basis of the criterion of having one (dominating) client who also decides on the working hours of the self-employed. ${ }^{3}$

As mentioned earlier, regarding start-up motive we distinguish between opportunity-driven, necessity-driven, and hybrid opportunity-necessity entrepreneurs. With respect to the last-mentioned type, we refer here to a particular type of entrepreneur

\footnotetext{
2 The study by A. Millán et al. (2020) is an exception.

3 Another school of thought (Williams \& Lapeyre, 2017; Williams \& Horodnic, 2019) within the recently emerging literature on dependent self-employment uses much broader criteria, where the right to hire employees also plays a role in the definition, leading to estimates as high as $47 \%$ of solo selfemployed in the European Union being dependent solo self-employed (Williams \& Lapeyre, 2017). In this paper we follow Cieślik and Dvouletý (2019) who argue that the criterion of the right to employ staff is "particularly questionable" because "For the overwhelming majority of solo self-employed, functioning without personnel is their modus operandi, so that such condition is not considered by them as a meaningful restriction." (p. 299). Following their recommendation in the present paper, we find $14.5 \%$ of the solo self-employed in the EU to be dependent self-employed.
} 
whose motivation to start a business is driven by both opportunity and necessity motives simultaneously (Caliendo \& Kritikos, 2019). ${ }^{4}$

The only studies that, to our knowledge, aim to identify the hybrid opportunity-necessity entrepreneurship type are those by Caliendo and Kritikos (2019) and Källner and Nyström (2018), despite the substantial empirical literature on opportunity and necessity entrepreneurship. In particular, Caliendo and Kritikos (2019) observe how start-ups out of opportunity and necessity have higher survival rates than do start-ups out of pure necessity. As regards the particular relation between the entrepreneur's start-up motive and earnings, the only available empirical evidence are the works by Andersson and Wadensjö (2007), Block and Wagner (2010), De Vries et al. (2020) and Van Stel et al. (2018). These studies, though, are based on relatively old data and/or a limited geographical coverage and, therefore, call for replication studies. ${ }^{5}$ Furthermore, none of them identify the aforementioned hybrid category. Thus, Andersson and Wadensjö (2007), Block and Wagner (2010) and De Vries et al. (2020) only consider opportunity and necessity entrepreneurs in their analyses whereas Van Stel et al. (2018) distinguish between six different and mutually exclusive reasons to start-up and, hence, hybrid motives are also not investigated. ${ }^{6}$ We contribute to extant literature by comparing hybrid opportunity-necessity entrepreneurs with pure opportunity and pure necessity entrepreneurs.

\section{Hypotheses}

A first comparison is between self-employed with employees and self-employed without employees (also known as solo self-employed). Extant literature has already found that the former group has higher earnings than the latter (Alba-Ramírez, 1994; Earle \& Sakova, 2000). ${ }^{7}$ Self-employed with employees are creating jobs for others, implying that they have had some success in their businesses, and that they have been able to secure capital and other inputs to work with their employees (Earle \& Sakova, 2000). In general, self-employment with employees implies working on a

\footnotetext{
${ }^{4}$ Some papers in the literature also use the term hybrid entrepreneurs referring to those individuals who retain their wage job while entering into self-employment (see, e.g., Folta et al., 2010; Raffiee \& Feng, 2014). To avoid any terminology misunderstanding with these hybrid entrants, we will mostly refer to our particular type of entrepreneurs throughout the paper as hybrid opportunity-necessity entrepreneurs.

5 Results by Andersson and Wadensjö (2007) are based on annual register data from Statistics Sweden for the period 1998-2002. Results by Block and Wagner (2010) are based on data drawn from the German Socio-Economic Panel (GSOEP) covering the period 1984-2004. Results by De Vries et al. (2020) are based on a sample of Dutch solo self-employed (drawn from panel data constructed ad-hoc) for the periods 2010 and 2011. Finally, results by Van Stel et al. (2018) are based on data drawn from the European Community Household Panel (ECHP) for the EU-15 covering the period 1994-2001.

${ }^{6}$ These authors compare earnings of those entrepreneurs who ended their previous job (proxy for startup motive) due to the following six different and mutually exclusive reasons: opportunity reasons (R1: obtained better/more suitable job), necessity reasons (R2: obliged to stop by employer; R3: end of contract; R4: sale/closure of own or family business), reasons related to family circumstances (R5: Family circumstances) or other reasons (R6: other reasons).

7 Admittedly, Hypothesis 1 is not a new hypothesis to the literature. However, we test the hypothesis in this paper to see if our data confirm findings from earlier literature.
} 
bigger scale than solo self-employment, which should normally also lead to higher earnings (Lucas, 1978; Sorgner et al., 2017).

Hypothesis 1: Among the self-employed, those with employees will earn more than those who work on a solo self-employed basis.

The solo self-employed form a very heterogeneous group of workers that differ on several dimensions (CRSE, 2017). However, a particularly useful distinction is based on the economic dependence associated with client diversification. We refer here to the distinction between independent own-account self-employed workers and dependent self-employed workers. Thus, independent own-account self-employed workers have multiple clients which enables them to set reasonable tariffs. In case the product or service that they sell is based on tacit knowledge, they are also able to sell the same knowledge-based product or service multiple times, leading to efficiency advantages and higher earnings (Burke, 2012). Moreover, the contribution of independent own-account workers to the economy is often bigger than what is visible from their own direct performance. This holds particularly for knowledge-based solo self-employed (sometimes called freelancers) as they tend to enable their client firms to be much more flexible and innovative than would have been possible by relying solely on their own employees (Burke \& Cowling, 2020).

By contrast, dependent self-employed workers are economically dependent in the sense that they are exclusively (or mainly) reliant on just one client enterprise (i.e., the outsourcing firm) (Supiot, 2001; Román et al., 2011). Hence, they generate their entire (or a substantial part of their) income from this business relationship and, obviously, take the entrepreneurial risk (Muehlberger \& Bertolini, 2008). The phenomenon of dependent self-employed workers reflects a general trend towards increasing labor market flexibility (Eichhorst et al., 2013), to which the growth of the gig economy, typified by online platforms and isolated independent workers, is severely contributing (Stewart \& Stanford, 2017). Dependent self-employed workers are often considered precarious as they tend to do similar work as normal employees but they do not enjoy social security protection in the same way as employees do (Muehlberger \& Bertolini, 2008; Quinlan, 2012; Atherton et al., 2018). They also tend to fall outside the scope of collective bargaining and trade union representation (Quinlan \& Johnstone, 2009). Indeed, it is unclear that existing regulations benefiting employees also apply to gig workers, let alone that they can be effectively enforced in the digital economy (Stewart \& Stanford, 2017). The precarious position of dependent self-employed workers may be expected to be also reflected in lower earnings. This gives rise to the following hypothesis:

Hypothesis 2: Among the solo self-employed, those who are independent with multiple clients will earn more than those who are dependent on a single client.

A second source of heterogeneity among the self-employed concerns their entrepreneurial motivation (Barba-Sánchez \& Atienza-Sahuquillo, 2017). First, there are those who enter self-employment to capture a new profit opportunity, i.e. individuals who freely choose an independent profession that enables them to materialize their 
visions (Constant \& Zimmermann, 2004). Second, there are those entering selfemployment due to a lack of paid-employment opportunities and who can be considered self-employed as a last resort (Alba-Ramírez, 1994; Mühlböck et al., 2018). This category includes those forced to work at their own risk because nobody else wants to take the risk of employing them.

Van Stel et al. (2018) argue that entrepreneurs who started a business because they spotted a business opportunity (opportunity entrepreneurs) may perform better than those who had no other options for work (necessity entrepreneurs). This may be the case, first, because entrepreneurial ability levels (including opportunity recognition; George et al., 2016) of opportunity entrepreneurs are expected to exceed those of their necessity counterparts. Second, this may be the case because opportunity entrepreneurs were able to take more time to carefully prepare their start-up effort, which positively influences business performance (Block \& Sandner, 2009). Third, as the opportunity costs of opportunity motivated entrepreneurs (typically a good wage income) are often higher than those of necessity entrepreneurs, opportunity entrepreneurs may also be more motivated to earn a high income as an entrepreneur, in order to at least match their opportunity costs (Block \& Wagner, 2010). The above arguments lead to the following hypothesis:

Hypothesis 3: Among the self-employed, those who started with an opportunity motive will earn more than those with a necessity motive.

However, the dichotomous classification of entrepreneurs into only two classes of motivation (i.e., those who initiate entrepreneurial activities voluntarily -opportunity entrepreneurs - and those who are pushed into such activities to address their lack of employment options -necessity entrepreneurs-) is not as straightforward as it seems (Williams, 2009). Thus, Caliendo and Kritikos (2019) raise doubts about this purely binary classification and suggest that not all unemployed start-ups are necessity entrepreneurs. Instead, they consider three groups: (i) those driven by opportunity or pull motives; (ii) those driven only by necessity or push motives; and (iii) those who become self-employed out of both opportunity-pull and necessity-push motives. ${ }^{8}$

More specifically, Källner and Nyström (2018) suggest the existence of such hybrid opportunity-necessity entrepreneurs among displaced employees, i.e., those employees losing their jobs due to the firm's failure or plant closure and not because of unsatisfactory job performance. Such employees are quite suddenly in need to look for alternative employment (necessity motive), but they may also see opportunities to exploit entrepreneurial ideas that they may have but never pursued while in a safe wage job (opportunity motive). Thus, work experience accumulated during an individual's career serves as a breeding ground for new business ideas (Politis, 2005; Shepherd \& DeTienne, 2005), which can be realized once these individuals decide to start-up a new venture (Abou Lebdi, 2017).

In this context, the decision to become an entrepreneur after displacement depends on (i) whether the individual has a business idea in which he or she has

\footnotetext{
${ }^{8}$ Caliendo and Kritikos (2019) find that start-ups out of opportunity and necessity have higher survival rates than do start-ups out of pure necessity.
} 
great confidence; (ii) the available job offers; and (iii) whether the individual meets the conditions to be eligible for unemployment benefits. Hence, those individuals with lower levels of educational attainment and/or entrepreneurial abilities would rarely start a new business in presence of unemployment benefits or alternative job offers. And only in absence of alternatives to make a living (i.e., when the opportunity cost of entrepreneurship is low), these pure necessity entrepreneurs would start-up. Conversely, those individuals who lose their job through no fault of their own (e.g., in case of organizational failure) but who do have higher endowments of human capital are more likely to exploit some of the innovative ideas which may be circulating within existing companies (Abou Lebdi, 2017; Källner \& Nyström, 2018). We refer here to hybrid opportunity-necessity entrepreneurs, from which their expected entrepreneurial income exceeds both expected wages and unemployment insurance benefits and, therefore, entrepreneurship is seen as an attractive choice. Hence:

Hypothesis 4: Among the self-employed, those who started with a hybrid opportunity-necessity motive will earn more than those with a pure necessity motive.

When comparing hybrid opportunity-necessity entrepreneurs with pure opportunity entrepreneurs, however, differences in entrepreneurial talent are not expected to be systematic and, hence, cannot be a source for unequal performance between both types. But the prior argument concerning the availability of time for a better preparation of the start-up endeavor still applies here (Block \& Sandner, 2009). Indeed, pure opportunity entrepreneurs are expected to take more time to properly design and set-up their venture, as compared with displaced workers. All in all, we hypothesize the following:

Hypothesis 5: Among the self-employed, those who started with a pure opportunity motive will earn more than those with a hybrid opportunity-necessity motive.

\section{Data and variables}

\section{Data and sample}

We use data from the Fifth and Sixth waves of the European Working Conditions Survey -EWCS 2010 and 2015- (Eurofound, 2012, 2016, 2018). This survey is carried out every five years by the EU Agency Eurofound (European Foundation for the Improvement of Living and Working Conditions) and offers key work-related information on 44,000 workers (including both employees and self-employed individuals) covering 35 European countries. ${ }^{9}$ These workers are interviewed about several working condition aspects, including physical environment, workplace design, working hours, work organization and social relationships in the workplace.

\footnotetext{
9 This set includes the EU-28 together, 5 candidate countries (Albania, the Former Yugoslav Republic of Macedonia, Montenegro, Serbia and Turkey) and 2 EFTA countries (Norway and Switzerland).
} 
Depending on country size and national arrangements, the sample ranges from 1000 to 4000 workers per country.

The EWCS 2010 and 2015 allow to create two separate classifications of selfemployed workers, based on self-classification. The first classification of selfemployed workers combines information collected from two different questions. First, the individuals in the survey are asked about their main activity status: selfemployed with employees, self-employed without employees, employed or other. Second, an additional question is asked to those respondents who previously indicated being self-employed without employees, i.e., whether his/her firm generally has more than one client. Based on this information, we classify self-employed workers within our dataset as (1) self-employed with employees; (2) independent own-account self-employed (i.e. self-employed without employees answering positively to the question on whether his/her firm generally has more than one client); and (3) dependent self-employed worker (i.e. self-employed without employees answering negatively to the question on whether his/her firm generally has more than one client). For the clarity of our exposition, we will refer, hereinafter, to this classification as professional status within self-employment. Our final sample includes men and women aged 18 to 65 who are classified as self-employed individuals within the EU-28 territory. All individuals working part-time, i.e., working under $15 \mathrm{~h}$ per week, are excluded. The final dataset, after removing cases with missing data for any of the relevant variables, yields 5136 observations.

The second classification of self-employed workers is created by means of a third question which is asked to those respondents who previously indicated being selfemployed either with or without employees, i.e., whether he or she became selfemployed mainly through own personal preference, because they had no other alternatives for work, due to a combination of both reasons, or due to neither of these reasons. Because this question was only used within the EWCS series in 2015, a subdataset was generated by excluding data from the EWCS 2010. Our subdataset when using data from the EWCS 2015 yields 2958 observations. Based on this information, we classify the observed self-employed workers within our dataset as (1) opportunity entrepreneur; (2) hybrid opportunity-necessity entrepreneur; (3) necessity entrepreneur; and (4) entrepreneur for other reasons. Henceforth, we will refer to this classification as start-up motivation.

\section{Dependent variable}

We are interested in explaining how professional status within self-employment and start-up motivation affect the business performance of entrepreneurs in terms of earnings. To this end, we employ the variable 'net monthly earnings'. Workers in the EWCS are asked to refer to their average net earnings in recent months and, in case they don't know, are asked to give an estimate. ${ }^{10}$ The variable is defined in PPP dollars of 2015 and converted to natural logarithms. ${ }^{11}$

\footnotetext{
10 The interviewer is asked to explain, if necessary, that net monthly earnings are the earnings at one's disposal after taxes and social security contributions.

11 Detailed definitions of all our variables are presented in Table 5 in the Appendix.
} 


\section{Main independent variables}

From the information on professional status within self-employment and start-up motivation described above, we generate the following two sets of dummy variables which are used as our main predictors of earnings:

(i) a set of three dummy variables: (i) a dummy equaling 1 for self-employed with employees; (ii) a dummy equaling 1 for independent own-account self-employed workers; and (iii) a dummy equaling 1 for dependent self-employed workers.

(ii) a set of four dummy variables: (i) a dummy equaling 1 for pure opportunity entrepreneurs; (ii) a dummy equaling 1 for hybrid opportunity-necessity entrepreneurs; (iii) a dummy equaling 1 for pure necessity entrepreneurs; and (iv) a dummy equaling 1 for entrepreneurs for other reasons.

\section{Control variables}

In order to isolate the effects of our hypotheses-related variables, the empirical models also include a set of explanatory variables that are known to influence selfemployment earnings (see, e.g., Hamilton, 2000; Block \& Wagner, 2010; Van Stel et al., 2018; Parker, 2018; Millán et al., 2014, 2020, 2021): educational attainment, job-related aspects (ICT use frequency at work, years of tenure, working hours, business sector) and some demographic indicators (gender, immigrant, age, cohabitation status, children, health status). In order to control for the business cycle and some structural differences between countries, the empirical models also include the national unemployment rates for periods 2010 and 2015, which we collect from Eurostat, and a period 2015 (vs. 2010) dummy.

\section{Descriptive analysis}

We first present main figures as regards the distribution of observations by professional status within self-employment and by start-up motivation for the EU-28. ${ }^{12}$

Concerning professional status, about $31.7 \%, 58.4 \%$ and $9.9 \%$ of our sample are, respectively, self-employed with employees, independent own-account selfemployed and dependent self-employed workers. These figures, however, vary substantially across European countries. For instance, the share of dependent self-employed workers rises above $23 \%$ in Romania whereas it lies below $3 \%$ in Denmark.

When concentrating on start-up motivation (only available for the EWCS 2015), $60.6 \%$ of our sample report to be pure opportunity entrepreneurs. As regards their pure necessity entrepreneurs counterparts, this group accounts for $20 \%$ of our sample. Finally, the groups of hybrid entrepreneurs and entrepreneurs for other reasons account for $16.4 \%$ and $3 \%$ of our sample. However, the shares of belonging to these

\footnotetext{
12 The whole distribution of observations across EU-28 countries is presented in Table 6 in the Appendix.
} 
groups vary substantially across European countries. For instance, the share of pure opportunity entrepreneurs is $81 \%$ for Denmark whereas it is only $54.2 \%$ for Romania. Similarly, the share of pure necessity entrepreneurs varies from $7.1 \%$ for Denmark to $35.6 \%$ for Romania.

We aim to explore how professional status within self-employment and start-up motivation affect earnings. Table 1 below compares earnings and all covariates for our entrepreneurship types.

We first explore how earnings vary by different professional statuses within selfemployment. When comparing earnings for the three groups, our results are consistent with Hypotheses 1 and 2. Thus, self-employed with employees have the highest earnings whereas dependent self-employed workers have the lowest. Nevertheless, it may be argued that with net monthly earnings of 1592 PPP dollar, dependent self-employed workers are still able to make a living. Turning our attention to startup motivation, our results give tentative support to our Hypotheses 3 to 5. Thus, pure opportunity entrepreneurs are observed to have the highest earnings whereas pure necessity entrepreneurs are observed to have the lowest. Analogously, with net monthly earnings of 1618 PPP dollar, it can be asserted that pure necessity entrepreneurs are also able to uphold. Finally, the groups of hybrid entrepreneurs and entrepreneurs for other reasons present intermediate positions in terms of earnings.

Next, we explore how our predictors of self-employment earnings vary by professional status. We observe in our sample that self-employed with employees are relatively more often male, better educated, more likely to use ICT at work, more often working in the industry, construction and commerce and hospitality sectors, and more often living with partner and children. They also work the longest hours and feel the healthiest. When comparing independent and dependent solo self-employed workers, the latter workers are lower educated, less likely to use ICT at work, older, and more likely to have worse health perceptions. They are also more likely to work in the agricultural sector than independent own-account self-employed.

When concentrating on start-up motive, similar profiles of our relevant groups are revealed. This is in spite of the fact that the percentage shares of these groups are quite different from those obtained for professional statuses. In particular, we observe how pure opportunity entrepreneurs in our sample are more often male, better educated, and more likely to use ICT at work. They also have better health perception, and work longer hours. In contrast, pure necessity entrepreneurs have the lowest educational attainment levels, they are the least likely to use ICT at work, they more often work in the agricultural sector and they have the worst health perception. Finally, the groups of hybrid entrepreneurs and entrepreneurs for other reasons present intermediate positions in terms of education levels and ICT use at work.

\section{Methodology}

As stated earlier, our data consist of two cross-sectional data sets, i.e., EWCS 2010 and 2015, grouped by country. In order to account for possible intra-country correlation when estimating earnings from self-employment, three different approaches, from weaker to stronger, are used. First, we use OLS regressions 


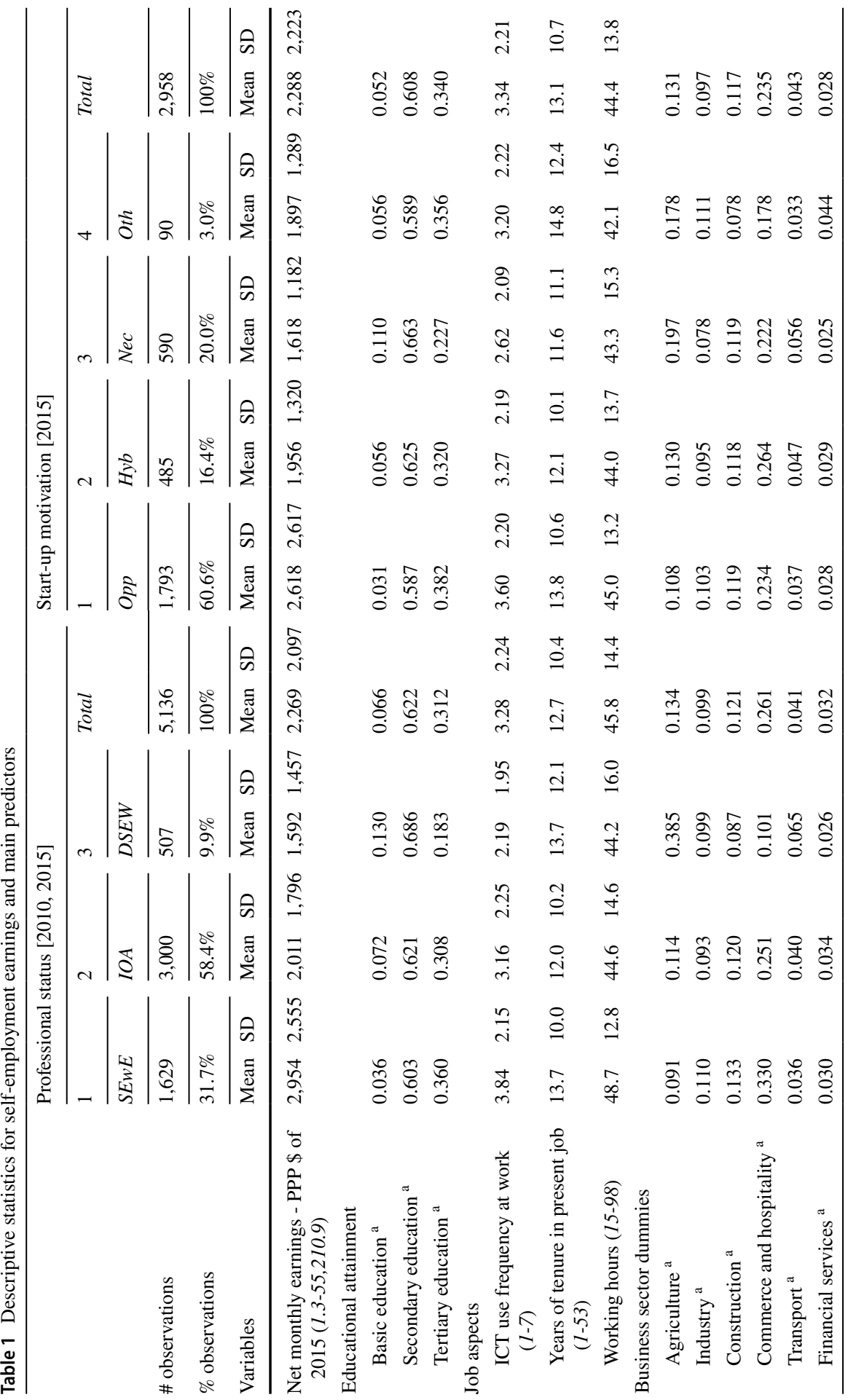




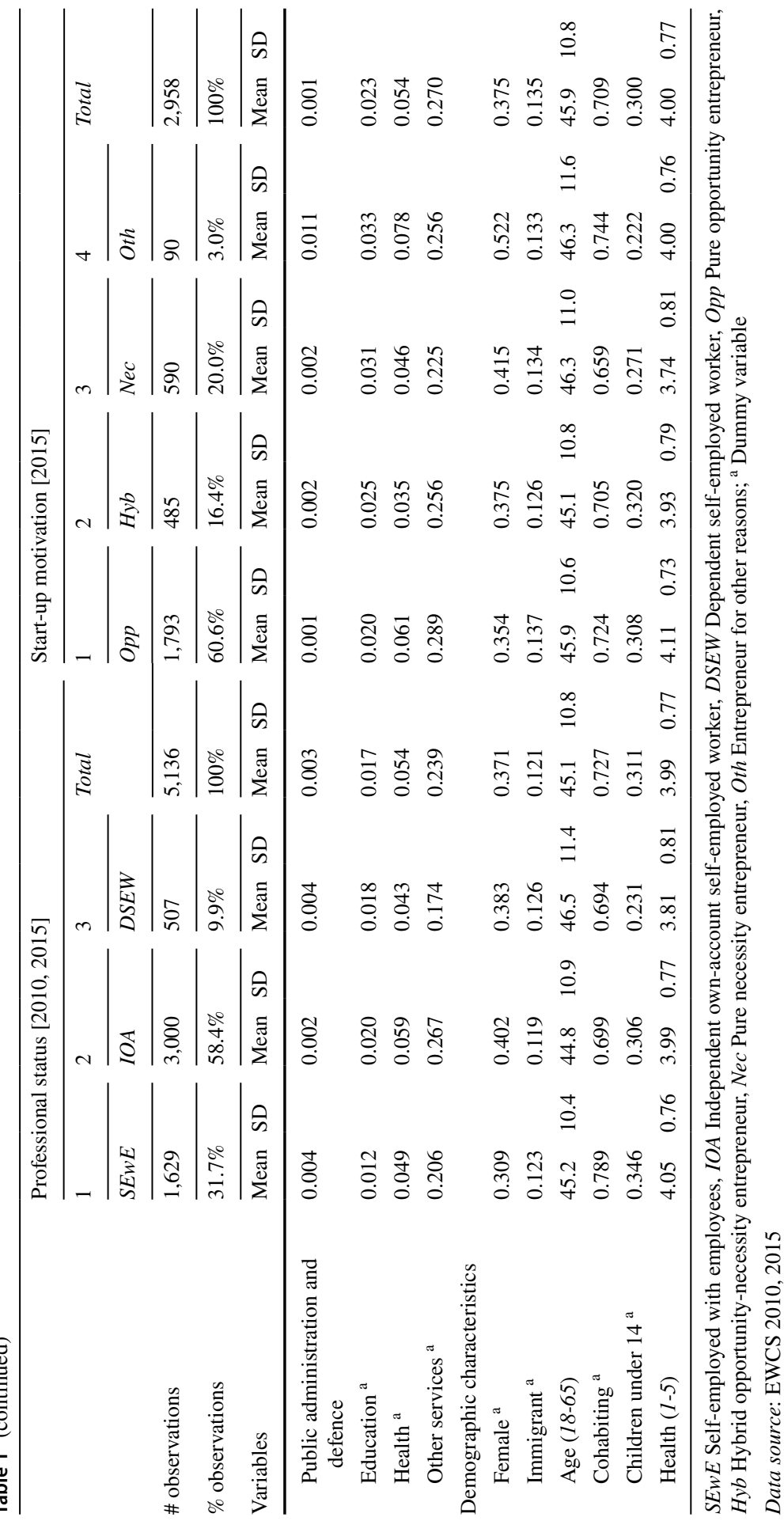


where standard errors are adjusted by country clustering. ${ }^{13}$ Second, we include country dummies in our OLS regressions, which allows for differences in the average level of earnings across countries, in addition to adjusting the standard errors taking into account the specific intra-group correlation. Finally, multilevel (hierarchical) models (Guo \& Zhao, 2000) are also used to further correct for biases in parameter estimates resulting from country groupings. In this framework, a significant between-group (in this case, countries) variance for the dependent variable is necessary as a precondition for running such a model (Hofmann, 1997; Bliese, 2000; Autio \& Acs, 2010). We therefore perform ANOVAs with net monthly earnings as endogenous variable and country group membership (i.e. a set of country dummies) as exogenous variables in order to obtain the intra-class correlation (ICC) coefficients.

The obtained ICC value is 0.193 and its confidence interval indicates that there is $95 \%$ chance that the true ICC value lands on any point between 0.100 and 0.286 . Therefore, the country effects compose approximately $19 \%$ of the total residual variance, which is within the normal range (5-20\%) that can be expected of grouped data of this nature (Bliese, 2000). These figures indicate that the country-level variance for the net monthly earnings is by no means negligible and puts into question whether the coefficients and standard errors from simple OLS regression without any control for intra-country correlation, are correct. The highly significant $F$ value (44.46) confirms that the earnings' means are not equal across countries, which also indicates the need to account for the specific intra-group correlation. ${ }^{14}$ All in all, using multilevel models is well-founded.

\section{Results}

Although our descriptive analysis in "Descriptive analysis" subsection seems to support the validity of our hypotheses, a conditional analysis is needed to draw robust conclusions. Models $1 \mathrm{~A}-1 \mathrm{C}$ in Table 2, which are presented in "Professional status within self-employment" subsection, explore the relationship between earnings and professional status within self-employment, while controlling for a wide range of possible alternative explanations of self-employment earnings. Similarly, Models $2 \mathrm{~A}-2 \mathrm{C}$ in Table 3, which are presented in "Start-up motivation" subsection, investigate the association between earnings and start-up motivation.

\footnotetext{
13 Regarding earnings from self-employment, a considerable proportion of observations are zeros in some human population surveys (see, e.g., Van Stel et al., 2018). In these cases the entrepreneur either only earns just enough to cover business expenses or might suffer losses (which are censored). This feature violates the linearity assumption so that the least squares method is inappropriate. As usual under these circumstances, earnings equations are estimated by means of tobit models (Tobin, 1958). This feature does not occur with our sample and, hence, using OLS seems a better option.

14 We also performed Bonferroni, Scheffe, and Sidak multiple comparison tests to examine the differences between each pair of earnings' means across the EU-28 countries. These tests apply corrections to the reported significance levels that take into account the fact that multiple comparisons are being conducted and, therefore, some differences could be significant just by chance. These tests reveal significant differences (at the $5 \%$ level) in about $60 \%$ of the 378 pairs of earnings' means.
} 
Models A are estimated by OLS where standard errors are adjusted by country clustering. These models include the unemployment rate as a means to control for cross-country differences (given that these models do not incorporate country dummies). Models B incorporate country dummies instead of national unemployment rates. Finally, multilevel (hierarchical) models are used in models $\mathrm{C}$, instead of simple OLS, to further correct for biases in parameter estimates resulting from country groupings.

The results in Tables 2 and 3 are presented as follows. Average predicted earnings are indicated at the top of each specification. These predicted earnings help to understand the relative importance of our marginal effects presented below. Thus, each specification is presented in a two-column format. The first column shows semi-elasticities in the form of $[(\mathrm{dy} / \mathrm{dx}) / \mathrm{y}] \%$, i.e., percentage changes of earnings caused by unit changes of the respective explanatory variables, whereas t-statistics associated with these effects are presented in the second column.

As regards the remainder of the fifth section, "Earnings across countries" subsection will present how estimated self-employment earnings vary across countries whereas "Control variables" subsection presents estimation results for our control variables. Next, "Robustness checks" subsection presents some robustness checks which are part of the analysis and, finally, a discussion of our main results is presented in "Discussion" subsection.

\section{Professional status within self-employment}

Table 2 shows the estimation results from three specifications, models $1 \mathrm{~A}-1 \mathrm{C}$, which are used to test our Hypotheses 1 and 2.

In coherence with Hypotheses 1 and 2, our results in models $1 \mathrm{~A}-1 \mathrm{C}$ show that self-employed with employees are associated with significantly higher entrepreneurial earnings whereas dependent self-employed workers are observed to have significantly lower earnings. ${ }^{15}$ Specifically, compared with independent own-account workers, average predicted earnings are observed to increase by about $33 \%$ for self-employed with employees, which is consistent with findings obtained by AlbaRamírez (1994) and Earle and Sakova (2000). Conversely, earnings are observed to be some 8 to $12 \%$ lower for dependent self-employed workers, as compared with independent own-account workers. This finding is in accordance with Millán et al. (2020), who find that dependent self-employed workers achieve worse job outcomes

\footnotetext{
15 Technically, Hypothesis 2 is tested and confirmed directly as earnings of dependent self-employed workers (DSE) are compared to those of the reference group of independent own-account workers (IOA), i.e. the negative and significant coefficient of DSE in Table 2 directly supports H2. Hypothesis 1 is also supported but this is by implication: it can be directly observed that self-employed with employees (SEWE) earn more than the reference group of IOA (the coefficient of SEWE is significant and positive in Table 2). However, for $\mathrm{H} 1$ to be supported, SEWE also need to earn more than DSE. This latter condition follows from the transitive relation between the three groups: since SEWE earn more than IOA, and IOA earn more than DSE (H2), it is also true that SEWE earn more than DSE. Hence, SEWE earn more than both categories of solo self-employed (IOA and DSE), and H1 is therefore supported.
} 


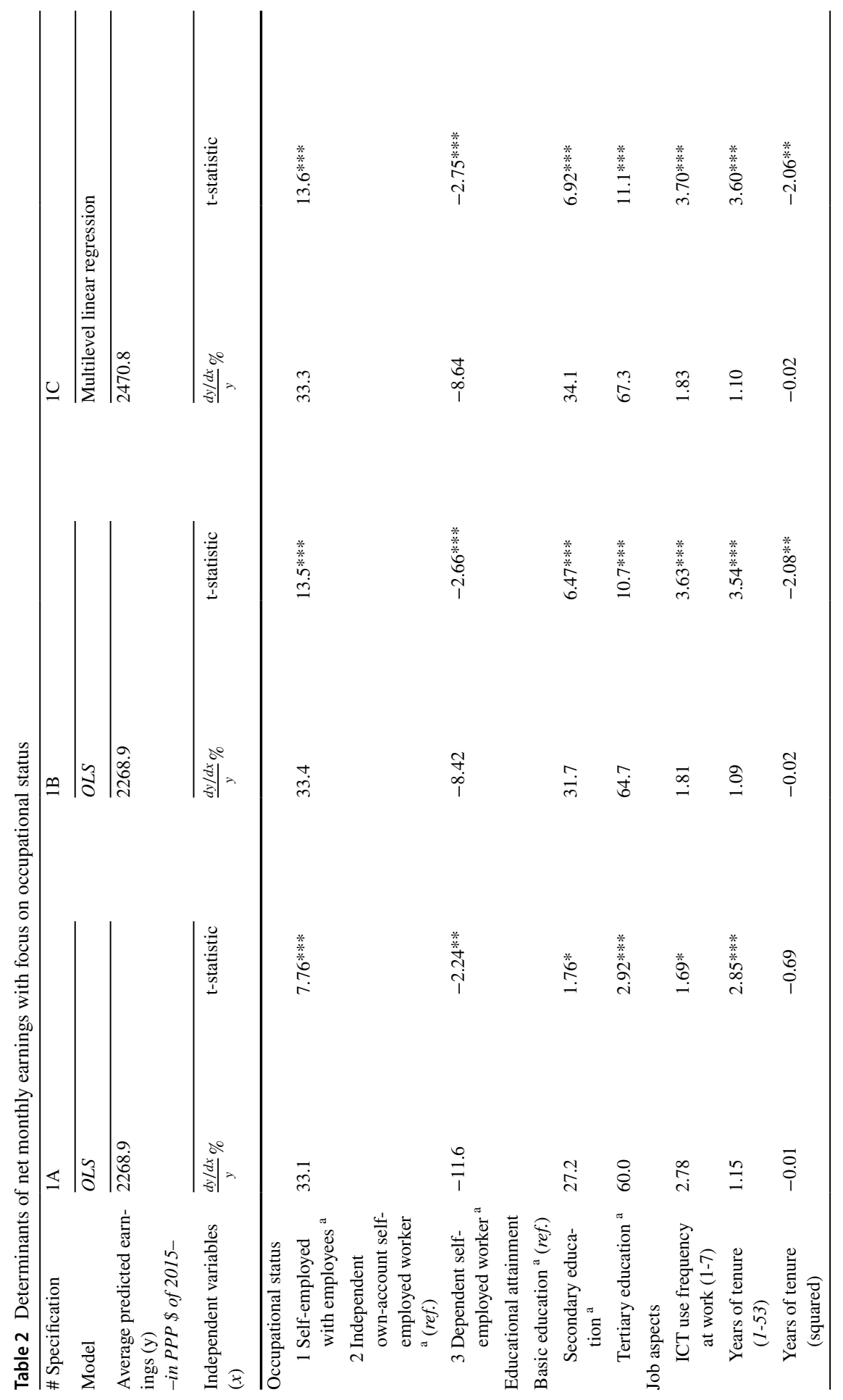




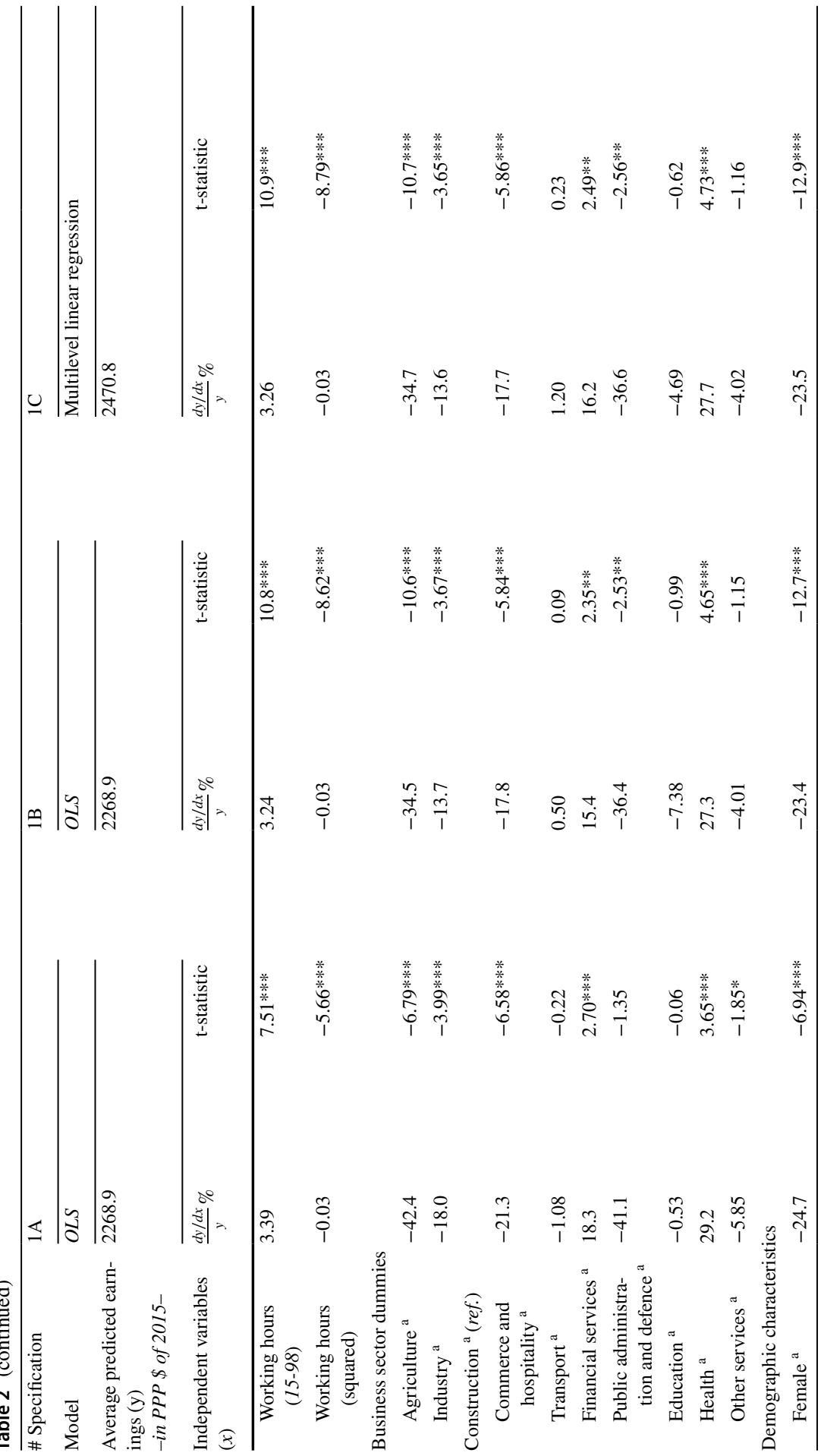




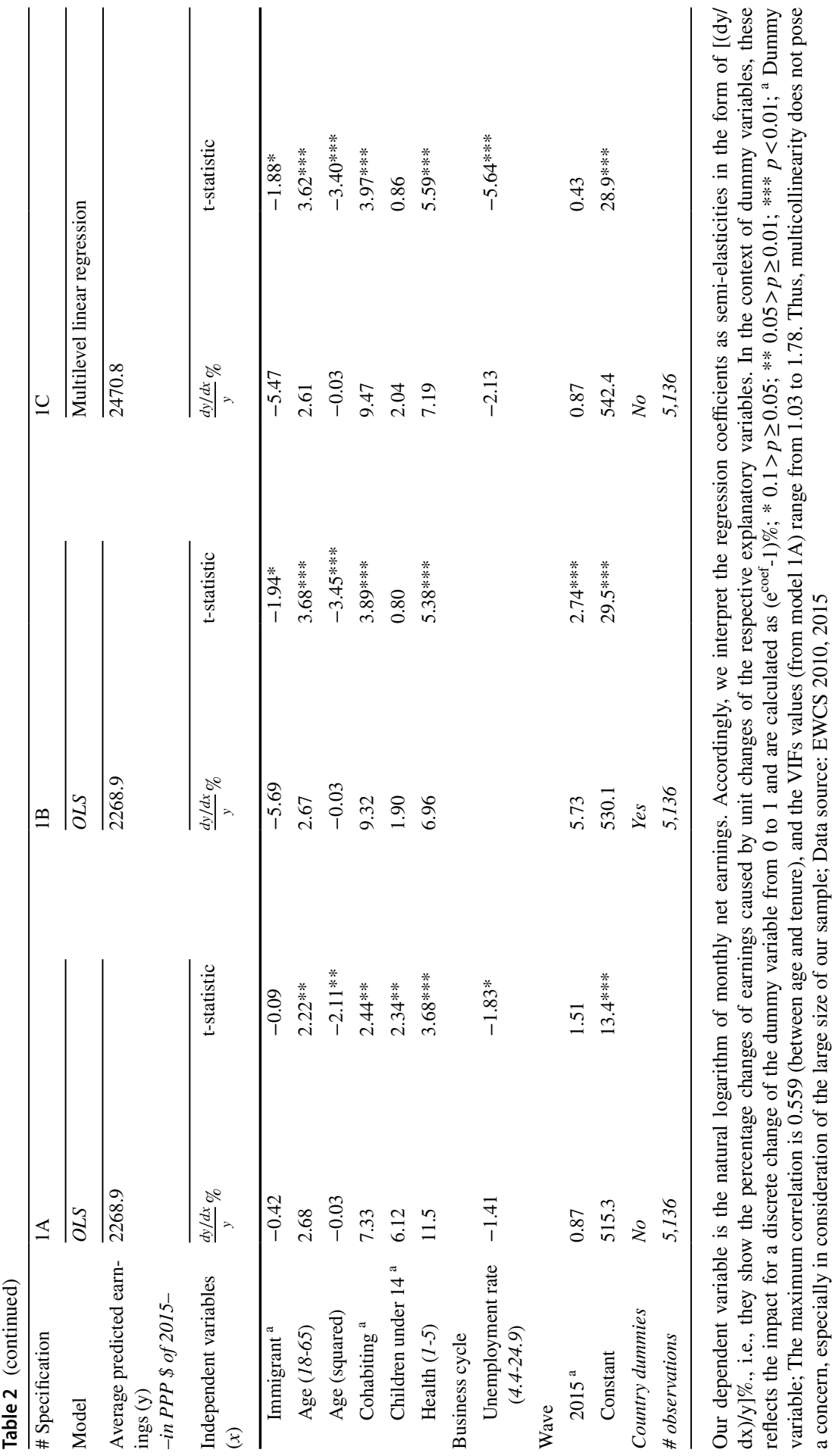




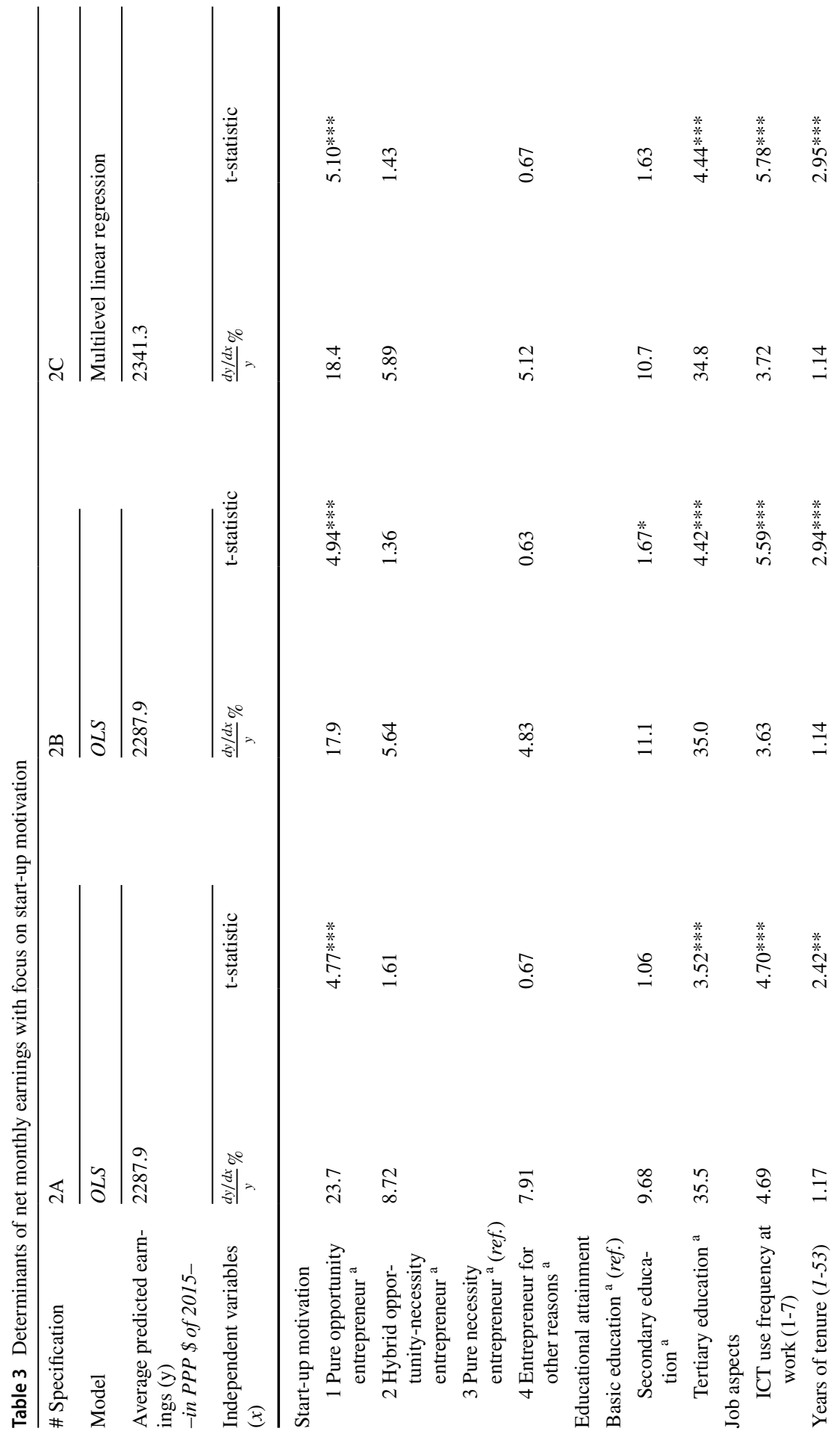




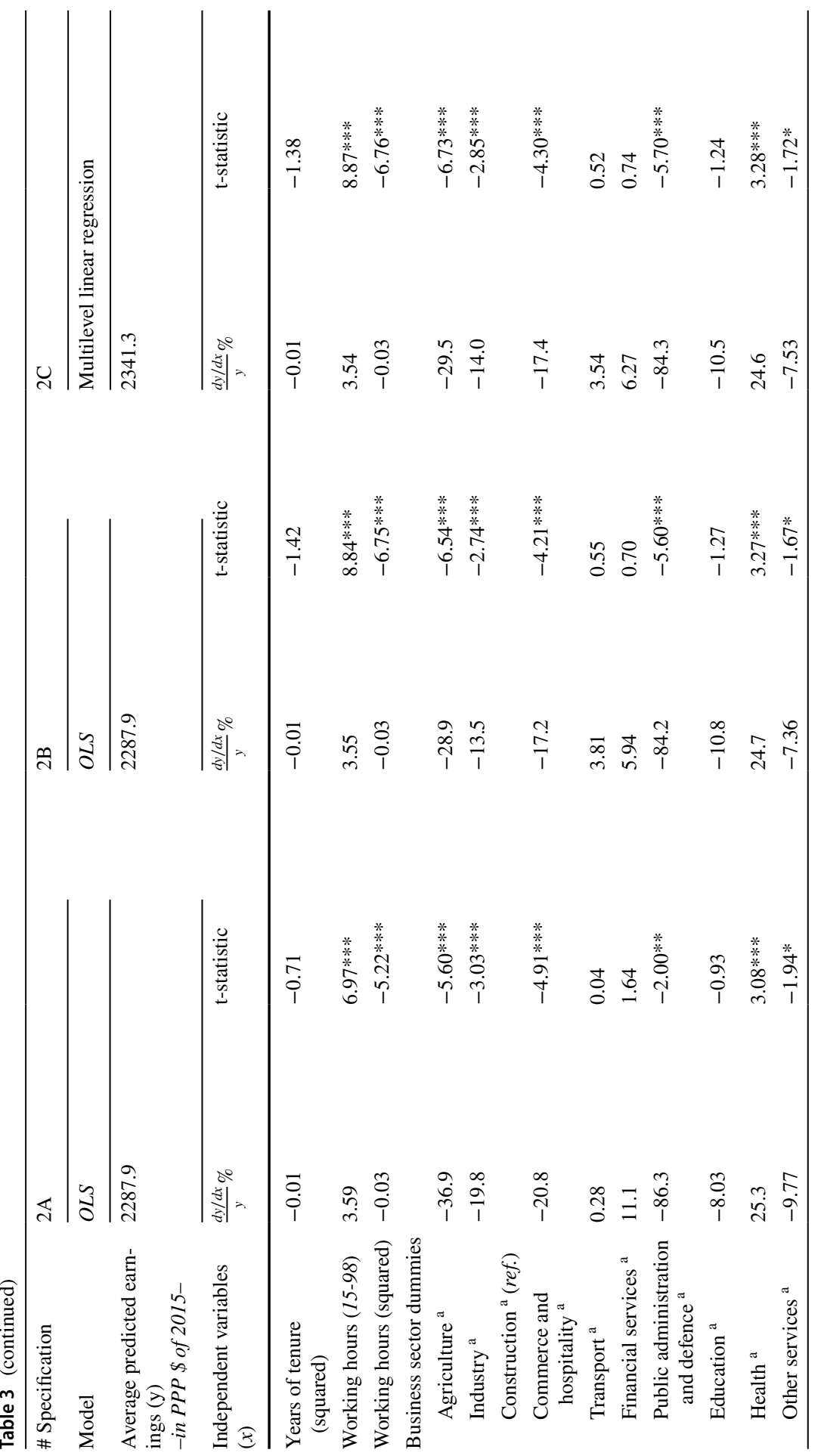




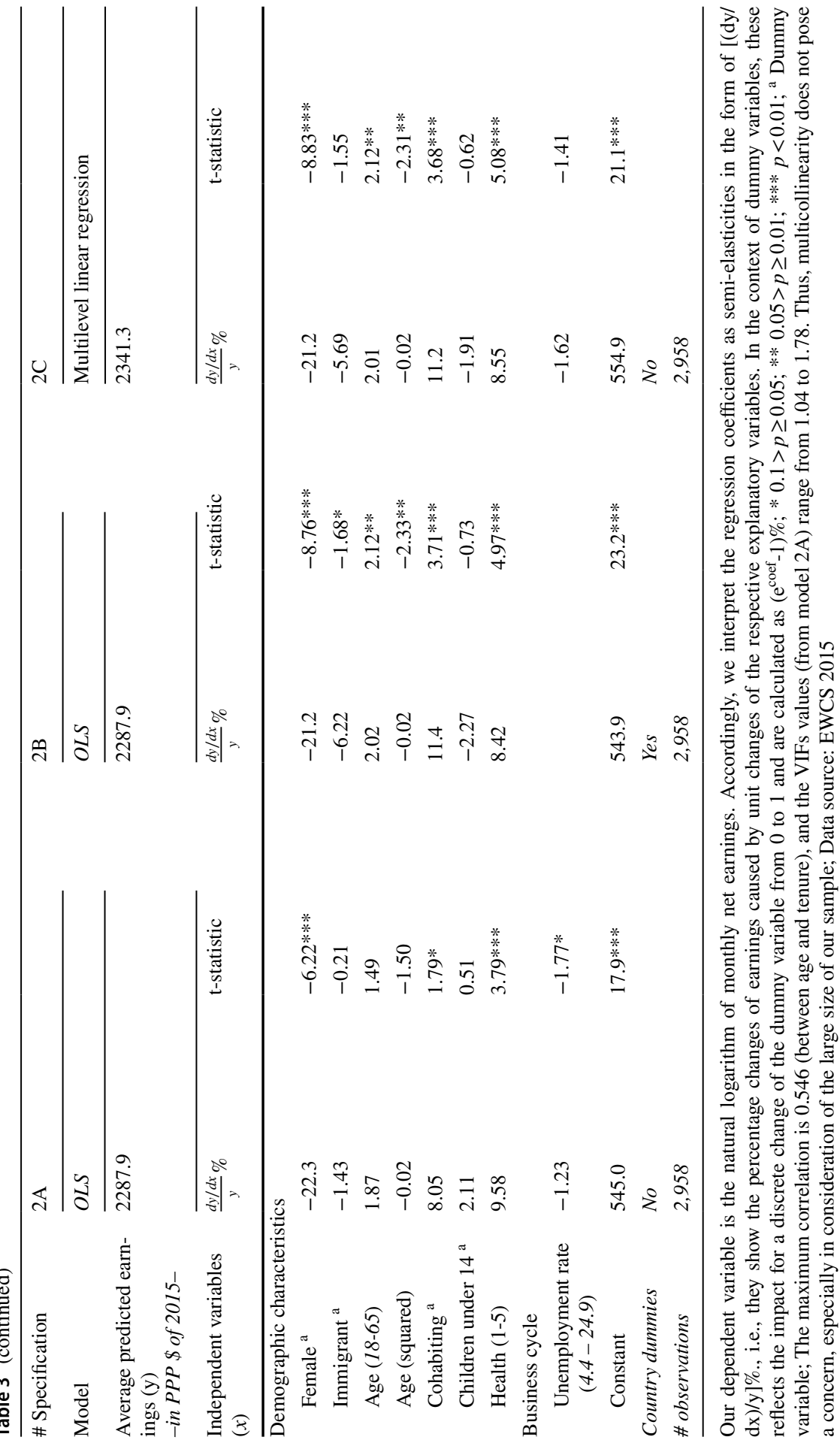


than independent own-account workers. ${ }^{16}$ All in all, these results give strong support to the statement that "while employers are rather clearly a successful group of entrepreneurs, the own-account workers occupy a much more ambiguous position" (Earle \& Sakova, 2000, p. 597).

\section{Start-up motivation}

Table 3 shows the estimation results from three specifications, models $2 \mathrm{~A}-2 \mathrm{C}$, which give support to our Hypotheses 3 and 5 but not to $\mathrm{H} 4$.

Thus, pure opportunity entrepreneurs present the highest earnings whereas hybrid opportunity-necessity entrepreneurs also present higher earnings than pure necessity entrepreneurs. In particular, compared with pure necessity entrepreneurs, average predicted earnings are observed to increase by between 18 and $24 \%$ for pure opportunity entrepreneurs (supporting H3), which is consistent with findings reported by Andersson and Wadensjö (2007), Block and Wagner (2010), De Vries et al. (2020) and Van Stel et al. (2018). In particular, the earnings differences, although notable, still seem to support the claim that "only a low proportion of necessity solo selfemployment may be considered precarious employment" (De Vries et al., 2020, p. 457). Compared with hybrid entrepreneurs, earnings are observed to be some 11.5 to $14 \%$ higher for pure opportunity entrepreneurs, supporting H5. ${ }^{17}$ Finally, earnings are observed to be between 5.5 and $9 \%$ lower for pure necessity entrepreneurs, as compared with hybrid entrepreneurs. Although the sign of this difference is in line with $\mathrm{H} 4$, the hypothesis is not formally supported, as the coefficient for hybrid entrepreneurs in Table 3 is not significant.

\section{Earnings across countries}

Table 4 shows differences in predicted average self-employment earnings across EU-28 countries for different professional statuses and start-up motivations.

Despite the fact that earnings are defined in PPP dollars of 2015, notable differences across groups of countries still remain, which may be associated to their institutional frameworks. ${ }^{18}$ Thus, we observe how both Anglo-Saxon (Ireland, UK) and Nordic countries (Denmark, Finland) rank high in terms of predicted self-employment earnings, Sweden being the only exception with a medium-low

\footnotetext{
16 This study analyses how dependent self-employed workers, independent own-account workers and paid employees compare in terms of job control, job demands and job returns. To this end, the authors first develop and validate a psychometrically sound multidimensional scale for these three key constructs by conducting both exploratory and confirmatory factor analysis.

17 In order to provide these results, we reestimated models $2 \mathrm{~A}-2 \mathrm{C}$ by using hybrid entrepreneurs as our reference category (not presented for brevity). These results are significant at conventional levels ( $p<0.01$ ), thereby formally supporting Hypothesis 5. Alternatively, these can be (roughly) calculated by simply subtracting the semi-elasticity associated to hybrid entrepreneur from the semi-elasticity associated to opportunity entrepreneur. By doing so, differences are also observed to vary between 12 and $15 \%$. 18 Undoubtedly, other factors are at play here as well, including macroeconomic factors. The analysis of the underlying factors explaining cross-country differences in self-employment earnings is beyond the scope of the present work.
} 
position. Continental countries also rank high (Netherlands, Luxembourg, Germany) or medium-high (Belgium, Austria, France) in terms of self-employment earnings. Mediterranean countries can be found in the whole range of intermediate positions, i.e., medium-high (Italy, Malta), medium (Cyprus, Spain) and medium-low positions (Portugal, Greece). Finally, both Baltic States and Eastern European countries occupy medium (Lithuania, Czech Republic), medium-low (Slovakia) and low positions (Estonia, Slovenia, Bulgaria, Croatia, Hungary, Romania, Latvia). ${ }^{19}$

\section{Control variables}

As regards the results for our control variables, we find that education, ICT use frequency at work, tenure, and the number of working hours increase earnings from entrepreneurship, as expected. As regards the number of working hours, however, the quadratic term begins to dominate the linear term at 61 working hours per week, indicating that, beyond this number of hours, additional entrepreneurial efforts are no longer productive. We also find that females and immigrants earn less than their male and native counterparts, respectively. Regarding the age of the entrepreneur, we find a non-linear, inverted U-shaped impact on earnings where the turning point is reached when the entrepreneur is 48 years old. Cohabiting individuals report higher earnings than those living without partner whereas no effect of children on earnings is observed. Reporting good health also seems to be positively associated with earnings from entrepreneurship. Finally, higher unemployment rates are associated with lower earnings, which is also as expected.

\section{Robustness checks}

We performed several robustness checks. First, our results are robust to quantile regression techniques, which is relevant as the distribution of entrepreneurs' incomes is very different from the distribution of employees' incomes (i.e., the variance is larger and the distribution is more skewed). Thus, mean earnings may not characterize the self-employment returns of the majority of business owners and, therefore, comparisons based on averages are likely to produce different results from those based on medians or other quantiles of the income distribution (Rosen, 1981; Hamilton, 2000). Second, we have obtained similar results when normalizing earnings by dividing by the corresponding country mean earnings and then taking the natural logarithm. Third, our results are similar to those obtained when considering other macroeconomic indicators such as GDP growth rates and GDP per capita (Eurostat) as alternative measures of macroeconomic conditions. Fourth, all models incorporated controls for intra-country correlation, as described in the fourth section. Results obtained with these approaches are similar to those obtained with simple pooled regressions. Fifth, in order to reach our final specifications, we followed a stepwise regression approach in which each new model only incorporates one new variant with respect to previous ones and serves as a robustness check for the obtained results in previous models. Finally, we verified the robustness of our t-statistics by re-estimating

19 Dilli et al. (2018) and Fritsch et al. (2019) present similar approaches to account for varieties of institutional contexts. 


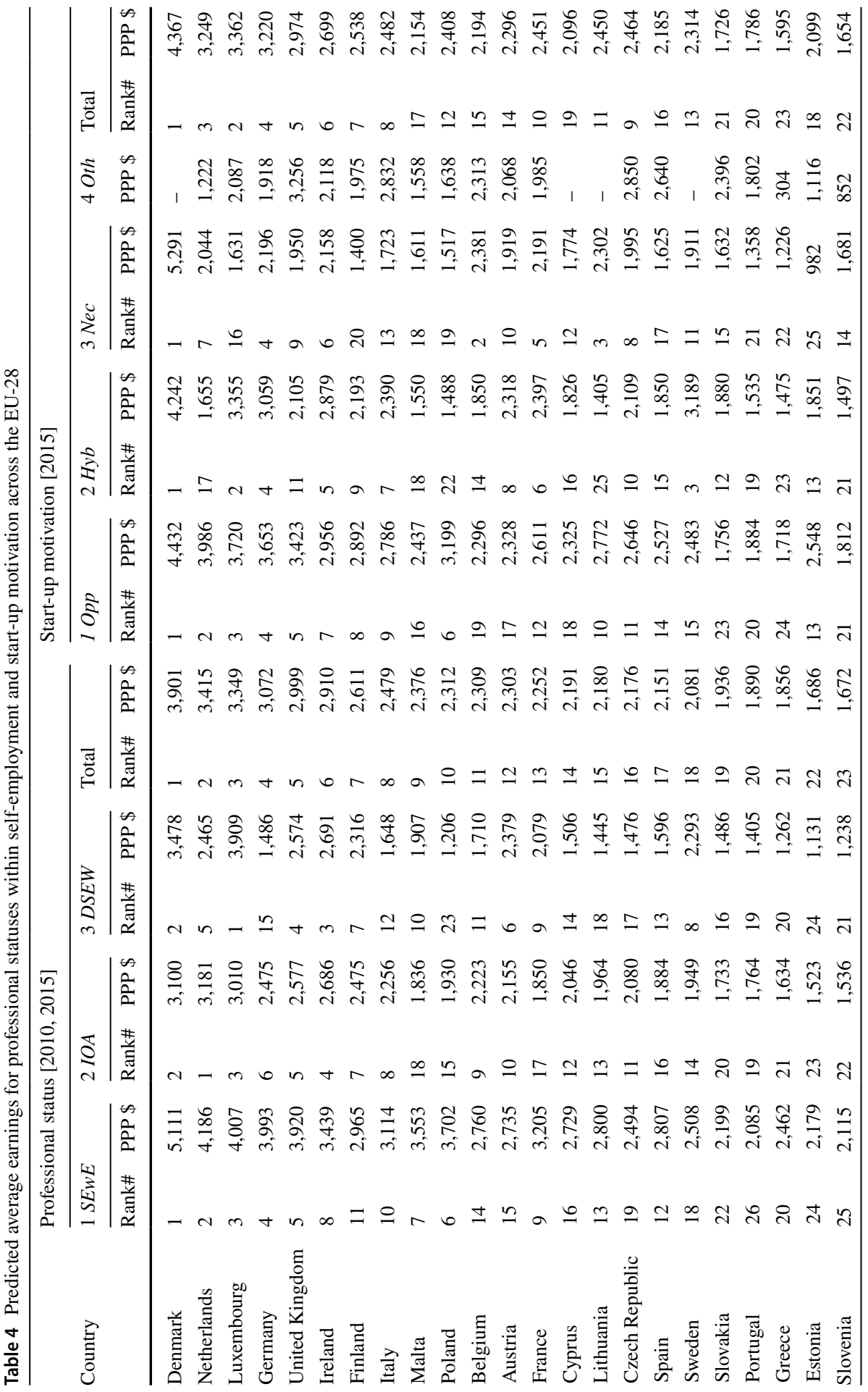




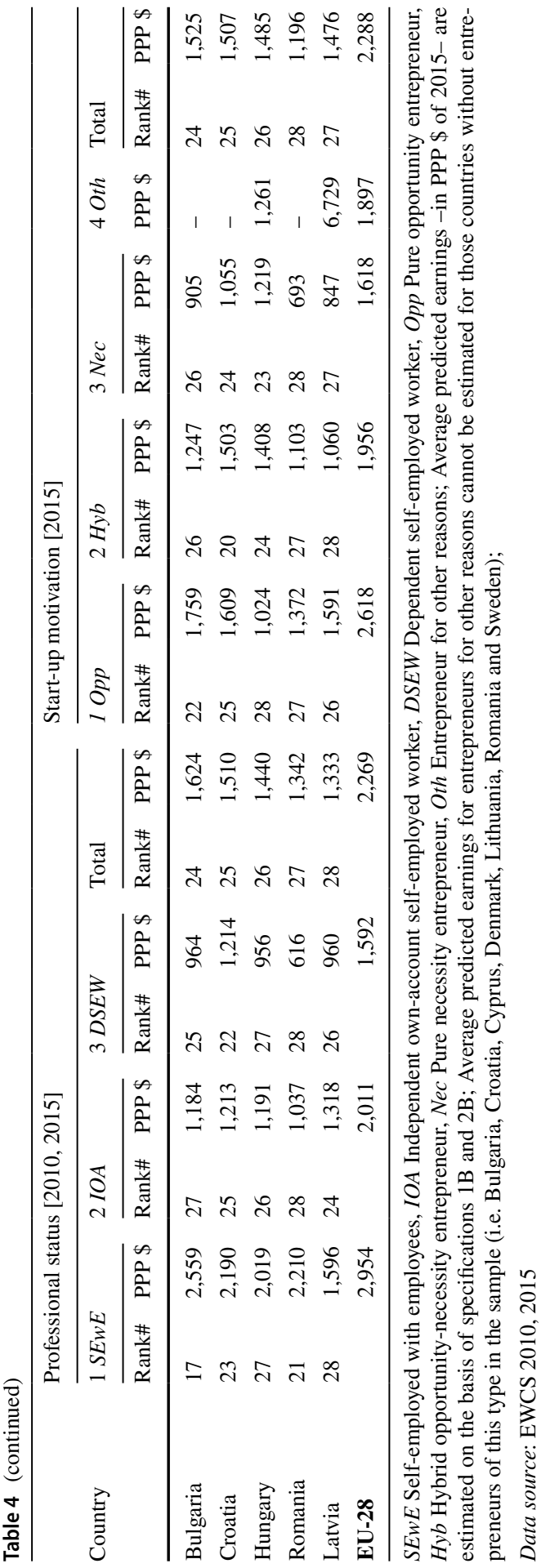


them from variance-covariance matrices of the coefficients obtained by bootstrapping. All results as regards these robustness checks are available upon request.

\section{Discussion}

Our results regarding dependent self-employed workers and necessity entrepreneurs may be a cause for concern as our results confirmed that they indeed earn significantly less than independent own-account self-employed and opportunity entrepreneurs, respectively. Governments may want to ask themselves if this type of employment is desirable and, in turn, whether 'erga omnes' policies, characterized by general and often automatic start-up subsidies, are appropriate. Thus, as Román et al. (2013) argue, if as part of active labor market policies, start-up incentives are intended to improve the chances of people moving back into work, they can be considered adequate instruments. On the contrary, if, as part of entrepreneurship policy, these incentives are considered as an instrument to promote more innovative and high-growth entrepreneurship, their contribution is dubious at the very least.

Since we are able to quantify earnings differentials between different groups, our paper actually makes a relevant contribution to the above debate. In particular regarding the category of dependent self-employed workers, there is a serious concern in various policy circles regarding the precarious nature of these workers (OECD, 2000, 2014; ILO, 2003; Supiot, 2001; European Commission, 2006; Eichhorst et al., 2013). The current paper found that in European countries, the dependent self-employed are indeed observed to have significantly lower earnings than independent own-account workers. However, it was also found that on average, dependent self-employed workers still generate average monthly earnings levels which are sufficient to make a living. Moreover, the difference in monthly earnings with independent own-account workers is only between 8 and $12 \%$. These findings suggest that the precarious nature of the dependent self-employed may be smaller than sometimes assumed by policy makers.

Possibly, many dependent self-employed workers may not be as unhappy with their employment as sometimes assumed, particularly if the alternative labour force status would be unemployment. Millán et al. (2020) find that, compared to paid employees and independent own-account self-employed, dependent self-employed workers are worse off in terms of job outcomes (including earnings), which is confirmed by the present study. However, both in terms of job control and in terms of job demands, the dependent self-employed take a middle position: they are better off than paid employees as far as job control is concerned, and they are better off than independent ownaccount self-employed as far as job demands are concerned (Millán et al., 2020). Hence, although dependent self-employment is certainly not the most ideal labour market position to be in, policy makers may want to carefully (re)consider how precarious the position of the dependent self-employed is. Obviously, more research is required to draw final conclusions in this regard, also in light of the current Covid-19 crisis. In case it will be concluded that dependent self-employment is undesirable, policy makers may consider lowering the extent of employment protection as this will make it more attractive for employers to offer workers a wage contract (Millán et al., 2013), rather than hiring their services on the basis of a dependent self-employment working relationship. 


\section{Conclusions}

Entrepreneurship is a heterogeneous phenomenon and different types of entrepreneurial activities contribute differently to economies and societies. Although this general notion is widely acknowledged within entrepreneurship research, empirical studies that quantify such differences in economic contribution between different entrepreneurship types, are scarce. This paper addresses this issue by investigating self-employment performance across different types, based on professional status and start-up motivation. In particular, we investigated which of our identified 'types' of self-employment perform better in terms of earnings. This is important since high-performance types are expected to provide a relatively bigger macro-economic contribution. We found that particularly the self-employed with employees and the opportunity entrepreneurs performed relatively well compared to other types of self-employed. Although this is hardly surprising, a contribution of our paper is that common assumptions regarding performance differences across different groups of entrepreneurs are actually confirmed by our study. Moreover, we have been able to quantify these differences and found that the earnings differential between pure opportunity and pure necessity entrepreneurs is about $18 \%$. Interestingly, hybrid opportunity-necessity entrepreneurs perform just in between the groups of pure opportunity and pure necessity entrepreneurs. This shows that the hybrid group should be distinguished as a separate group in future research on start-up motives.

We cannot rule out the possibility that our results are affected to some extent by data limitations. We particularly refer to the lack of panel data, which does not allow examining the dynamics behind the professional status choices observed in the data base. Clearly, more research is needed to determine whether other international data bases (in particular those with a longitudinal set-up) reinforce the robustness of our results or not. A second data limitation concerns the entrepreneurs' working conditions that may affect earnings. Although we have included several controls capturing working conditions, it is possible that our estimation results are still influenced somewhat by the omission of certain specific working conditions like the physical environment or the workplace design.

Nevertheless, we suggest that our results form a good starting point for the study of heterogeneity within entrepreneurship. However, we are aware that our dimensions of professional status and start-up motivation certainly do not frame the entire scope of entrepreneurship. Accordingly, future research should broaden the horizons of the present enquiry by extending the analysis to other categorizations of self-employed and entrepreneurs. In this regard, Wennekers and Van Stel (2017, p. 41) identify 20 entrepreneurship dimensions along which entrepreneurship types can be identified, including innovative vs. imitative entrepreneurship, start-ups vs. incumbent entrepreneurship, female vs. male entrepreneurship, to give only a few examples. Considering that in this paper we only explored two such dimensions, there is certainly still a lot of research ahead in this area.

Future research may also focus on examining other measures of performance (e.g., survival or employment growth), and other (non-European) countries. Finally, future studies should also investigate to what extent performance differences between different entrepreneurship types are reinforced or attenuated by the current Covid-19 crisis, and how different types of entrepreneurs cope with the challenge of maintaining their liquidity during the crisis (Block et al., 2020). 


\section{Appendix}

Table 5 Variable definitions

Variable Description

Earnings

Net monthly earnings - PPP \$ of $2015(\log s)$

Occupational status within self-employment

Self-employed with employees

Independent own-account self-employed worker

Dependent self-employed worker

Start-up motivation

Pure opportunity entrepreneur

Hybrid opportunity-necessity entrepreneur

Pure necessity entrepreneur

Entrepreneur for other reasons

Educational attainment

Basic education

Secondary education

Tertiary education

\section{Dependent variable}

Average net earnings in recent months. The variable is defined in PPP \$ of 2015 and converted to natural logarithms.

\section{Main independent variables}

Dummy equals 1 for workers who declare being self-employed with employees.

Dummy equals 1 for workers who declare being self-employed without employees and answer positively to the question on whether he/she generally has more than one client or customer.

Dummy equals 1 for workers who declare being self-employed without employees and answer negatively to the question on whether he/she generally has more than one client or customer.

Dummy equals 1 for workers who declare having become self-employed mainly through own personal preferences. This variable is generated for the year 2015 .

Dummy equals 1 for workers who declare having become self-employed due to a combination of both reasons: own personal preferences and no other alternatives for work. This variable is generated for the year 2015 .

Dummy equals 1 for workers who declare having become self-employed because had no other alternatives for work. This variable is generated for the year 2015 .

Dummy equals 1 for workers who declare having become self-employed due to neither of these previous reasons. This variable is generated for the year 2015 .

\section{Control variables}

Dummy equals 1 for workers with less than lower secondary education (ISCED-1997, 0-1).

Dummy equals 1 for workers with, at least, lower secondary education but non-tertiary education (ISCED-1997, 2-4).

Dummy equals 1 for workers with tertiary education (ISCED-1997, 5-6). 
Table 5 (continued)

\begin{tabular}{|c|c|}
\hline Variable & Description \\
\hline \multicolumn{2}{|l|}{ Job aspects } \\
\hline ICT use frequency at work & $\begin{array}{l}\text { Variable ranging from } 1 \text { to } 7 \text {. The scale refers to the } \\
\text { individual ICT (i.e., computers, laptops, smart- } \\
\text { phones, etc.) use frequency at work. It equals } 1 \text { for } \\
\text { individuals answering never and } 7 \text { for individuals } \\
\text { answering all of the time. }\end{array}$ \\
\hline Years of tenure & Years of experience in the company or organization. \\
\hline Working hours & Working hours per week. \\
\hline \multicolumn{2}{|l|}{ Business sector dummies } \\
\hline Agriculture & $\begin{array}{l}\text { Dummy equals } 1 \text { for workers whose code of main } \\
\text { activity of the local unit of the business, by means } \\
\text { of the Nomenclature of Economic Activities } \\
\text { (NACE rev. 2, 2008) is A= Agriculture, forestry } \\
\text { and fishing. }\end{array}$ \\
\hline Industry & $\begin{array}{l}\text { Dummy equals } 1 \text { for workers whose codes of main } \\
\text { activity of the local unit of the business, by means } \\
\text { of the Nomenclature of Economic Activities } \\
\text { (NACE rev. 2, 2008) are B= Mining and quarry- } \\
\text { ing, } \mathrm{C}=\text { Manufacturing, } \mathrm{D}=\text { Electricity, gas, steam } \\
\text { and air conditioning supply, and E= Water supply; } \\
\text { sewerage, waste management and remediation } \\
\text { activities. }\end{array}$ \\
\hline Construction & $\begin{array}{l}\text { Dummy equals } 1 \text { for workers whose code of main } \\
\text { activity of the local unit of the business, by means } \\
\text { of the Nomenclature of Economic Activities } \\
\text { (NACE rev. 2, 2008) is F=Construction. }\end{array}$ \\
\hline Commerce and hospitality & $\begin{array}{l}\text { Dummy equals } 1 \text { for workers whose codes of main } \\
\text { activity of the local unit of the business, by means } \\
\text { of the Nomenclature of Economic Activities } \\
\text { (NACE rev. } 2,2008 \text { ) are } \mathrm{G}=\text { Wholesale and retail } \\
\text { trade; repair of motor vehicles and motorcycles, } \\
\text { and } \mathrm{I}=\text { Accommodation and food service activi- } \\
\text { ties. }\end{array}$ \\
\hline Transport & $\begin{array}{l}\text { Dummy equals } 1 \text { for workers whose code of main } \\
\text { activity of the local unit of the business, by means } \\
\text { of the Nomenclature of Economic Activities } \\
\text { (NACE rev. 2, 2008) is } \mathrm{H}=\text { Transportation and } \\
\text { storage. }\end{array}$ \\
\hline Financial services & $\begin{array}{l}\text { Dummy equals } 1 \text { for workers whose codes of main } \\
\text { activity of the local unit of the business, by means } \\
\text { of the Nomenclature of Economic Activities } \\
\text { (NACE rev. } 2,2008 \text { ) are } \mathrm{K}=\text { Financial and insur- } \\
\text { ance activities, and L= Real estate activities. }\end{array}$ \\
\hline Public administration and defence & $\begin{array}{l}\text { Dummy equals } 1 \text { for workers whose code of main } \\
\text { activity of the local unit of the business, by means } \\
\text { of the Nomenclature of Economic Activities } \\
\text { (NACE rev. 2, 2008) is } \mathrm{O}=\text { Public administration } \\
\text { and defence; compulsory social security. }\end{array}$ \\
\hline
\end{tabular}


Table 5 (continued)

\begin{tabular}{|c|c|}
\hline Variable & Description \\
\hline Education & $\begin{array}{l}\text { Dummy equals } 1 \text { for workers whose code of main } \\
\text { activity of the local unit of the business, by means } \\
\text { of the Nomenclature of Economic Activities } \\
\text { (NACE rev. 2, 2008) is } \mathrm{P}=\text { Education. }\end{array}$ \\
\hline Health & $\begin{array}{l}\text { Dummy equals } 1 \text { for workers whose code of main } \\
\text { activity of the local unit of the business, by means } \\
\text { of the Nomenclature of Economic Activities } \\
\text { (NACE rev. 2, 2008) is } \mathrm{Q}=\text { Human health and } \\
\text { social work activities. }\end{array}$ \\
\hline Other services & $\begin{array}{l}\text { Dummy equals } 1 \text { for workers whose codes of main } \\
\text { activity of the local unit of the business, by means } \\
\text { of the Nomenclature of Economic Activities } \\
\text { (NACE rev. } 2,2008 \text { ) are } \mathrm{J}=\text { Information and } \\
\text { communication, } \mathrm{M}=\text { Professional, scientific and } \\
\text { technical activities, } \mathrm{N}=\text { Administrative and sup- } \\
\text { port service activities, } \mathrm{R}=\text { Arts, entertainment and } \\
\text { recreation, } \mathrm{S}=\text { Other service activities, } \mathrm{T}=\text { Activi- } \\
\text { ties of households as employers; undifferenti- } \\
\text { ated goods- and services-producing activities of } \\
\text { households for own use, and } \mathrm{U}=\text { Activities of } \\
\text { extraterritorial organisations and bodies. }\end{array}$ \\
\hline \multicolumn{2}{|c|}{ Demographic characteristics } \\
\hline Female & Dummy equals 1 for females. \\
\hline Immigrant & $\begin{array}{l}\text { Dummy equals } 1 \text { for citizens of a different country } \\
\text { of that of residence. }\end{array}$ \\
\hline Age & Age reported by the workers. \\
\hline Cohabiting & $\begin{array}{l}\text { Dummy equals } 1 \text { for individuals cohabiting with } \\
\text { spouse/partner. }\end{array}$ \\
\hline Children under 14 & $\begin{array}{l}\text { Dummy equals } 1 \text { for individuals cohabiting with any } \\
\text { son or daughter aged under } 14 \text {. }\end{array}$ \\
\hline Health & $\begin{array}{l}\text { Variable ranging from } 1 \text { to } 5 \text {. The scale refers to the } \\
\text { level of health declared by the worker. It equals } 1 \\
\text { for individuals whose health is very bad and } 5 \text { for } \\
\text { individuals whose health is very good. }\end{array}$ \\
\hline \multicolumn{2}{|l|}{ Business cycle } \\
\hline Unemployment rate & $\begin{array}{l}\text { Harmonised annual unemployment rate (source: } \\
\text { Eurostat). }\end{array}$ \\
\hline \multicolumn{2}{|l|}{ Wave } \\
\hline 2015 & $\begin{array}{l}\text { Dummy equals } 1 \text { for observations corresponding to } \\
\text { the EWCS } 2015 \text { and } 0 \text { for observations corre- } \\
\text { sponding to the EWCS } 2010 \text {. }\end{array}$ \\
\hline Country dummies & $\begin{array}{l}28 \text { dummies equalling } 1 \text { for individuals living in } \\
\text { the named country: Austria, Belgium, Bulgaria, } \\
\text { Croatia, Cyprus, Czech Republic, Denmark, Esto- } \\
\text { nia, Finland, France, Germany, Greece, Hungary, } \\
\text { Ireland, Italy, Latvia, Lithuania, Luxembourg, } \\
\text { Malta, Netherlands, Poland, Portugal, Romania, } \\
\text { Slovakia, Slovenia, Spain, Sweden, and the United } \\
\text { Kingdom. }\end{array}$ \\
\hline
\end{tabular}


Table 6 Distribution of observations by professional status within self-employment and start-up motivation for the EU-28

\begin{tabular}{|c|c|c|c|c|c|c|c|c|c|c|}
\hline \multirow[b]{3}{*}{ Country } & & \multicolumn{4}{|c|}{ Professional status [2010, 2015] } & \multicolumn{5}{|c|}{ Start-up motivation [2015] } \\
\hline & & \multirow{2}{*}{$\begin{array}{l}1 \\
\text { SEwE }\end{array}$} & \multirow{2}{*}{$\begin{array}{l}2 \\
I O A\end{array}$} & 3 & Total & \multirow{2}{*}{$\begin{array}{l}1 \\
\text { Opp }\end{array}$} & \multirow{2}{*}{$\begin{array}{l}2 \\
H y b\end{array}$} & \multirow{2}{*}{$\begin{array}{l}3 \\
\mathrm{Nec}\end{array}$} & \multirow{2}{*}{$\begin{array}{l}4 \\
\text { Oth }\end{array}$} & \multirow[t]{2}{*}{ Total } \\
\hline & & & & \multicolumn{2}{|l|}{ DSEW } & & & & & \\
\hline \multirow[t]{2}{*}{ Austria } & $\%$ obs. & 33.6 & 58.8 & 7.6 & 100 & 39.1 & 16.1 & 29.9 & 14.9 & 100 \\
\hline & \# obs. & 44 & 77 & 10 & 131 & 34 & 14 & 26 & 13 & 87 \\
\hline \multirow[t]{2}{*}{ Belgium } & $\%$ obs. & 36.8 & 59.5 & 3.7 & 100 & 77.4 & 5.1 & 10.8 & 6.7 & 100 \\
\hline & \# obs. & 141 & 228 & 14 & 383 & 151 & 10 & 21 & 13 & 195 \\
\hline \multirow[t]{2}{*}{ Bulgaria } & $\%$ obs. & 32.1 & 60.3 & 7.7 & 100 & 66.7 & 12.2 & 21.1 & 0.0 & 100 \\
\hline & \# obs. & 50 & 94 & 12 & 156 & 60 & 11 & 19 & 0 & 90 \\
\hline \multirow[t]{2}{*}{ Croatia } & $\%$ obs. & 35.9 & 50.9 & 13.2 & 100 & 39.7 & 22.4 & 37.9 & 0.0 & 100 \\
\hline & \# obs. & 38 & 54 & 14 & 106 & 23 & 13 & 22 & 0 & 58 \\
\hline \multirow[t]{2}{*}{ Cyprus } & $\%$ obs. & 38.7 & 49.4 & 11.9 & 100 & 77.3 & 12.8 & 9.9 & 0.0 & 100 \\
\hline & \# obs. & 101 & 129 & 31 & 261 & 109 & 18 & 14 & 0 & 141 \\
\hline \multirow[t]{2}{*}{ Czech Republic } & $\%$ obs. & 27.6 & 63.8 & 8.6 & 100 & 50.8 & 29.2 & 18.5 & 1.5 & 100 \\
\hline & \# obs. & 45 & 104 & 14 & 163 & 33 & 19 & 12 & 1 & 65 \\
\hline \multirow[t]{2}{*}{ Denmark } & $\%$ obs. & 49.6 & 47.8 & 2.7 & 100 & 81.0 & 11.9 & 7.1 & 0.0 & 100 \\
\hline & \# obs. & 56 & 54 & 3 & 113 & 34 & 5 & 3 & 0 & 42 \\
\hline \multirow[t]{2}{*}{ Estonia } & $\%$ obs. & 45.6 & 45.6 & 8.7 & 100 & 59.4 & 12.5 & 21.9 & 6.3 & 100 \\
\hline & \# obs. & 47 & 47 & 9 & 103 & 38 & 8 & 14 & 4 & 64 \\
\hline \multirow[t]{2}{*}{ Finland } & $\%$ obs. & 36.8 & 52.6 & 10.5 & 100 & 80.3 & 11.3 & 6.3 & 2.1 & 100 \\
\hline & \# obs. & 70 & 100 & 20 & 190 & 114 & 16 & 9 & 3 & 142 \\
\hline \multirow[t]{2}{*}{ France } & $\%$ obs. & 29.6 & 66.6 & 3.8 & 100 & 65.3 & 18.4 & 12.2 & 4.1 & 100 \\
\hline & \# obs. & 93 & 209 & 12 & 314 & 64 & 18 & 12 & 4 & 98 \\
\hline \multirow[t]{2}{*}{ Germany ${ }^{a}$} & $\%$ obs. & 49.6 & 45.3 & 5.0 & 100 & 56.5 & 22.5 & 19.1 & 2.0 & 100 \\
\hline & \# obs. & 69 & 63 & 7 & 139 & 83 & 33 & 28 & 3 & 147 \\
\hline \multirow[t]{2}{*}{ Greece } & $\%$ obs. & 25.5 & 61.1 & 13.3 & 100 & 45.9 & 26.8 & 24.9 & 2.4 & 100 \\
\hline & \# obs. & 94 & 225 & 49 & 368 & 94 & 55 & 51 & 5 & 205 \\
\hline Hungary & $\%$ obs. & 33.7 & 56.1 & 10.2 & 100 & 25.7 & 31.4 & 31.4 & 11.4 & 100 \\
\hline & \# obs. & 33 & 55 & 10 & 98 & 9 & 11 & 11 & 4 & 35 \\
\hline Ireland & $\%$ obs. & 33.8 & 53.3 & 12.9 & 100 & 68.9 & 11.9 & 17.8 & 1.5 & 100 \\
\hline & \# obs. & 71 & 112 & 27 & 210 & 93 & 16 & 24 & 2 & 135 \\
\hline Italy & $\%$ obs. & 30.4 & 61.6 & 8.0 & 100 & 55.8 & 22.1 & 19.5 & 2.6 & 100 \\
\hline & \# obs. & 84 & 170 & 22 & 276 & 86 & 34 & 30 & 4 & 154 \\
\hline Latvia & $\%$ obs. & 38.6 & 48.9 & 12.5 & 100 & 37.5 & 26.6 & 34.4 & 1.6 & 100 \\
\hline & \# obs. & 34 & 43 & 11 & 88 & 24 & 17 & 22 & 1 & 64 \\
\hline Lithuania & $\%$ obs. & 23.5 & 58.3 & 18.3 & 100 & 56.4 & 18.0 & 25.6 & 0.0 & 100 \\
\hline & \# obs. & 27 & 67 & 21 & 115 & 44 & 14 & 20 & 0 & 78 \\
\hline Luxembourg & $\%$ obs. & 41.4 & 53.5 & 5.1 & 100 & 76.2 & 12.7 & 6.4 & 4.8 & 100 \\
\hline & \# obs. & 41 & 53 & 5 & 99 & 48 & 8 & 4 & 3 & 63 \\
\hline Malta & $\%$ obs. & 28.8 & 64.4 & 6.8 & 100 & 68.8 & 12.5 & 17.5 & 1.3 & 100 \\
\hline & \# obs. & 38 & 85 & 9 & 132 & 55 & 10 & 14 & 1 & 80 \\
\hline
\end{tabular}


Table 6 (continued)

\begin{tabular}{|c|c|c|c|c|c|c|c|c|c|c|}
\hline \multirow[b]{3}{*}{ Country } & & \multicolumn{4}{|c|}{ Professional status [2010, 2015] } & \multicolumn{5}{|c|}{ Start-up motivation [2015] } \\
\hline & & 1 & 2 & 3 & Total & 1 & 2 & 3 & 4 & Total \\
\hline & & $S E w E$ & $I O A$ & $D S E W$ & & $O p p$ & $H y b$ & $\mathrm{Nec}$ & Oth & \\
\hline \multirow[t]{2}{*}{ Netherlands } & $\%$ obs. & 27.1 & 66.3 & 6.6 & 100 & 72.8 & 14.6 & 7.8 & 4.9 & 100 \\
\hline & \# obs. & 45 & 110 & 11 & 166 & 75 & 15 & 8 & 5 & 103 \\
\hline \multirow[t]{2}{*}{ Poland } & $\%$ obs. & 22.9 & 60.6 & 16.5 & 100 & 49.2 & 20.0 & 23.1 & 7.7 & 100 \\
\hline & \# obs. & 43 & 114 & 31 & 188 & 32 & 13 & 15 & 5 & 65 \\
\hline \multirow[t]{2}{*}{ Portugal } & $\%$ obs. & 24.7 & 59.2 & 16.1 & 100 & 40.6 & 17.8 & 37.6 & 4.0 & 100 \\
\hline & \# obs. & 43 & 103 & 28 & 174 & 41 & 18 & 38 & 4 & 101 \\
\hline \multirow[t]{2}{*}{ Romania } & $\%$ obs. & 23.2 & 53.5 & 23.2 & 100 & 54.2 & 10.2 & 35.6 & 0.0 & 100 \\
\hline & \# obs. & 33 & 76 & 33 & 142 & 32 & 6 & 21 & 0 & 59 \\
\hline \multirow[t]{2}{*}{ Slovakia } & $\%$ obs. & 20.6 & 61.2 & 18.2 & 100 & 66.7 & 11.1 & 20.8 & 1.4 & 100 \\
\hline & \# obs. & 35 & 104 & 31 & 170 & 48 & 8 & 15 & 1 & 72 \\
\hline \multirow[t]{2}{*}{ Slovenia } & $\%$ obs. & 32.0 & 55.7 & 12.3 & 100 & 64.2 & 15.0 & 15.0 & 5.8 & 100 \\
\hline & \# obs. & 65 & 113 & 25 & 203 & 77 & 18 & 18 & 7 & 120 \\
\hline \multirow[t]{2}{*}{ Spain } & $\%$ obs. & 30.3 & 63.5 & 6.2 & 100 & 47.8 & 19.6 & 31.3 & 1.4 & 100 \\
\hline & \# obs. & 103 & 216 & 21 & 340 & 139 & 57 & 91 & 4 & 291 \\
\hline \multirow[t]{2}{*}{ Sweden } & $\%$ obs. & 34.0 & 63.1 & 2.9 & 100 & 86.5 & 7.7 & 5.8 & 0.0 & 100 \\
\hline & \# obs. & 35 & 65 & 3 & 103 & 45 & 4 & 3 & 0 & 52 \\
\hline \multirow[t]{2}{*}{ United Kingdom } & $\%$ obs. & 24.9 & 63.4 & 11.7 & 100 & 71.1 & 10.5 & 16.5 & 2.0 & 100 \\
\hline & \# obs. & 51 & 130 & 24 & 205 & 108 & 16 & 25 & 3 & 152 \\
\hline \multirow[t]{2}{*}{$E U-28$} & $\%$ obs. & 31.7 & 58.4 & 9.9 & 100 & 60.6 & 16.4 & 20.0 & 3.0 & 100 \\
\hline & \# obs. & 1,629 & 3,000 & 507 & 5,136 & 1,793 & 485 & 590 & 90 & 2,958 \\
\hline
\end{tabular}

SEwE Self-employed with employees, IOA Independent own-account self-employed worker, DSEW Dependent self-employed worker, $O p p$ Pure opportunity entrepreneur, $H y b$ Hybrid opportunity-necessity entrepreneur, Nec Pure necessity entrepreneur, Oth Entrepreneur for other reasons; ${ }^{a}$ Germany has to be excluded from our sample for 2010 due to missing data in relevant variables

Data source: EWCS 2010, 2015 and Eurostat

Acknowledgements All authors contributed equally to the manuscript. The authors would like to thank Juan A. Sanchis-Llopis (University of Valencia, Spain) and two anonymous reviewers for their insightful comments that contributed substantially to the development of this paper. The work has benefited from comments from participants at the Workshop Knowledge Frontiers and Entrepreneurship held at the Indiana University Europe Gateway (Berlín, 2018) and sponsored by the British Academy, where an earlier version of this paper was presented. This paper is part of Leonel Caçador-Rodrigues's doctoral dissertation, which has been written under the framework of the PhD Program in Economics, Business, Finance and Computer Science at the University of Huelva and the International University of Andalusia, Spain.

Funding The study was supported by the Polish National Science Centre, Polish Ministry of Science and Higher Education, under research project 2015/19/B/HS4/00366 (Self-employment from Polish and international perspective); the Spanish Ministry of Economy and Competitiveness (Ministerio de Economía y Competitividad) under research projects ECO2017-86305-C4-2-R and ECO2017-86402-C2-2-R; the Ministry of Economy and Knowledge of the Andalusian Regional Government (Junta de AndalucíaConsejería de Economía y Conocimiento) through Research Group SEJ-487 (Spanish Entrepreneurship Research Group - SERG) and Andalusia ERDF 2014-20 Operational Programme (Programa Operativo FEDER Andalucía 2014-20) under PAIDI 2020 research project PY20_00733 and University of Huelva 
research project UHU-1265299; and University of Huelva through Research and Transfer Policy Strategies (Estrategias de Política de Investigación y Transferencia).

\section{Declarations}

Conflict of interest The authors declare no conflict of interest.

\section{References}

Abou Lebdi, N. (2017). The role of corporate parent support for spinoff innovation performance. International Review of Entrepreneurship, 15(2), 203-226.

Acs, Z. J. (2006). How is entrepreneurship good for economic growth? Innovations: Technology, Governance Globalization, 1(1), 97-107.

Alba-Ramírez, A. (1994). Self-employment in the midst of unemployment: The case of Spain and the United States. Applied Economics, 26(3), 189-204. https://doi.org/10.1080/00036849400000001.

Andersson, P., \& Wadensjö, E. (2007). Do the unemployed become successful entrepreneurs? International Journal of Manpower, 28(7), 604-626. https://doi.org/10.1108/01437720710830070.

Atherton, A., Wu, D., \& Wu, Z. (2018). Self-exploitation or successful entrepreneurship? The effects of personal capital on variable outcomes from self-employment. Journal of Small Business and Enterprise Development, 25(6), 866-885. https://doi.org/10.1108/JSBED-02-2018-0048.

Audretsch, D. B., \& Thurik, R. (2004). A model of the entrepreneurial economy. International Journal of Entrepreneurship Education, 2(2), 143-166.

Autio, E., \& Acs, Z. J. (2010). Intellectual property protection and the formation of entrepreneurial growth aspirations. Strategic Entrepreneurship Journal, 4(3), 234-251. https://doi.org/10.1002/sej. 93.

Barba-Sánchez, V., \& Atienza-Sahuquillo, C. (2017). Entrepreneurial motivation and self-employment: Evidence from expectancy theory. International Entrepreneurship and Management Journal, 13(4), 1097-1115. https://doi.org/10.1007/s11365-017-0441-z.

Baumol, W. (1990). Entrepreneurship: productive, unproductive and destructive. Journal of Political Economy, 98(5), 893-921. Reprinted in Journal of Business Venturing, 11(1), 1996, 3-22. http:// www.jstor.org/stable/2937617.

Bliese, P. D. (2000). Within-group agreement, non-independence, and reliability: Implications for data aggregation and analysis. In K. J. Klein \& S. W. J. Kozlowski (Eds.), Multilevel theory, research, and methods in organizations: Foundations, extensions, and new directions (pp. 349-381). Jossey-Bass.

Block, J. H., \& Sandner, P. (2009). Necessity and opportunity entrepreneurs and their duration in selfemployment: Evidence from German micro data. Journal of Industry, Competition and Trade, 9(2), 117-137. https://doi.org/10.1007/s10842-007-0029-3.

Block, J. H., \& Wagner, M. (2010). Necessity and opportunity entrepreneurs in Germany: Characteristics and earnings differentials. Schmalenbach Business Review, 62(2), 154-174. https://doi.org/10.1007/ BF03396803.

Block, J. H., Fisch, C., \& Hirschmann, M. (2020). Solo self-employed individuals and bootstrap financing in the COVID-19 crisis. Working paper available at SSRN (draft 12 May 2020): https://ssrn.com/ abstract=3598818. Accessed 1 April 2021.

Böheim, R., \& Muehlberger, U. (2009). Dependent self-employment: Workers between employment and self-employment in the UK. Journal of Labour Market Research, 42(2), 182-195. https://doi.org/10. 1007/s12651-009-0014-x.

Burchell, B., Deakin, S., \& Honey, S. (1999). The employment status of individuals in non-standard employment. Employment Relations Research Series No. 6. London: Department of Trade and Industry. http://citeseerx.ist.psu.edu/viewdoc/download?doi=10.1.1.594.173\&rep=rep1\&type=pdf. Accessed 1 April 2021.

Burke, A. E. (2012). The role of freelancers in the $21^{\text {st }}$ century British economy. Centre for Research on Self-Employment (CRSE), London. https://www.ipse.co.uk/resource/the-role-of-freelancers-in-the21st-century-british-economy-report.html. Accessed 1 April 2021. 
Burke, A., \& Cowling, M. (2020). The relationship between freelance workforce intensity, business performance and job creation. Small Business Economics, 55(2), 399-413. https://doi.org/10.1007/ s11187-019-00241-X.

Caliendo, M., \& Kritikos, A. S. (2019). "I want to, but I also need to": Start-ups resulting from opportunity and necessity. In E. E. Lehmann \& M. Keilbach (Eds.), From industrial organization to entrepreneurship: A tribute to David B. Audretsch (pp. 247-265). Springer.

Carrasco, R. (1999). Transitions to and from self-employment in Spain: An empirical analysis. Oxford Bulletin of Economics and Statistics, 61(3), 315-341. https://doi.org/10.1111/1468-0084.00132.

Cieślik, J., \& Dvouletý, O. (2019). Segmentation of the population of the solo self-employed. International Review of Entrepreneurship, 17(3), 281-304.

Constant, A., \& Zimmermann, K. F. (2004). Self-employment dynamics across the business cycle: migrants versus natives. IZA Discussion Paper No. 1386. http://anon-ftp.iza.org/dp1386.pdf. Accessed 1 April 2021.

CRSE (2017). The true diversity of self-employment. Centre for Research on Self-Employment (CRSE), London. https://www.tcd.ie/business/assets/pdf/The-true-diversity-of-self-employment.pdf. Accessed 1 April 2021.

De Vries, N., Liebregts, W., \& Van Stel, A. (2020). Explaining entrepreneurial performance of solo selfemployed from a motivational perspective. Small Business Economics, 55(2), 447-460. https://doi. org/10.1007/s11187-019-00244-8.

Dennis, W. J. (1996). Self-employment: When nothing else is available? Journal of Labor Research, 17(4), 645-661. https://doi.org/10.1007/bf02685805.

Dilli, S., Elert, N., \& Herrmann, A. M. (2018). Varieties of entrepreneurship: Exploring the institutional foundations of different entrepreneurship types through 'varieties-of-capitalism' arguments. Small Business Economics, 51(2), 293-320. https://doi.org/10.1007/s11187-018-0002-z.

Earle, J. S., \& Sakova, Z. (2000). Business start-ups or disguised unemployment? Evidence on the character of self-employment from transition economies. Labour Economics, 7(5), 575-601. https://doi. org/10.1016/S0927-5371(00)00014-2.

Eichhorst, W., Braga, M., Mühlberger, U., Gerard, M., Horvath, T., Kahanec, M., Kahancová, M., Kendzia, M., Martišková, M., Monti, P., Pedersen, J.L., Stanley, J., Vandeweghe, B., Wehner, C., \& White, C. (2013). Social protection rights of economically dependent self-employed workers. Policy Department A - Economic and Scientific Policy, European Parliament. European Parliament. http:// www.europarl.europa.eu/RegData/etudes/etudes/join/2013/507449/IPOL-EMPL_ET\%282013\% 29507449_EN.pdf. Accessed 1 April 2021.

Eurofound (2012). Fifth European Working Conditions Survey - Overview report. Publications Office of the European Union. https://www.eurofound.europa.eu/sites/default/files/ef_publication/field_ef_ document/ef1182en.pdf. Accessed 1 April 2021.

Eurofound (2016). Sixth European Working Conditions Survey - Overview report. Publications Office of the European Union. https://www.eurofound.europa.eu/sites/default/files/ef_publication/field_ef_ document/ef1634en.pdf. Accessed 1 April 2021.

Eurofound (2018). European Working Conditions Survey Integrated Data File, 1991-2015. [data collection]. 7th Edition. UK Data Service. SN: 7363. https://doi.org/10.5255/UKDA-SN-7363-7.

European Commission. (2006). Green Paper. Modernising labour law to meet the challenges of the $21^{\text {st }}$ century. European Commission. http://www.europarl.europa.eu/meetdocs/2004_2009/documents/ com/com_com(2006)0708_/com_com(2006)0708_en.pdf. Accessed 1 April 2021.

Folta, T. B., Delmar, F., \& Wennberg, K. (2010). Hybrid entrepreneurship. Management Science, 56(2), 253-269. https://doi.org/10.1287/mnsc.1090.1094.

Fritsch, M. (2013). New business formation and regional development: A survey and assessment of the evidence. Foundations and Trends in Entrepreneurship, 9(3), 249-364. https://doi.org/10.1561/ 0300000043 .

Fritsch, M., Sorgner, A., \& Wyrwich, M. (2019). Self-employment and well-being across institutional contexts. Journal of Business Venturing, 34(6), 105946. https://doi.org/10.1016/j.jbusvent.2019. 105946.

George, N. M., Parida, V., Lahti, T., \& Wincent, J. (2016). A systematic literature review of entrepreneurial opportunity recognition: Insights on influencing factors. International Entrepreneurship and Management Journal, 12(2), 309-350. https://doi.org/10.1007/s11365-014-0347-y.

Guo, G., \& Zhao, H. (2000). Multilevel modeling for binary data. Annual Review of Sociology, 26, 441462. https://doi.org/10.1146/annurev.soc.26.1.441. 
Hamilton, R. T. (2000). Does entrepreneurship pay? An empirical analysis of the returns to self-employment. Journal of Political Economy, 108(3), 604-631. https://doi.org/10.1086/262131.

Henrekson, M., \& Johansson, D. (2010). Gazelles as job creators: A survey and interpretation of the evidence. Small Business Economics, 35(2), 227-244. https://doi.org/10.1007/s11187-009-9172-z.

Hofmann, D. A. (1997). An overview of the logic and rationale of hierarchical linear models. Journal of Management, 23(6), 723-744. https://doi.org/10.1177/014920639702300602.

ILO (2003). The scope of the employment relationship. Report V. Paper presented at the International Labour Conference, 91st Session, Geneva. http://www.ilo.org/public/english/standards/relm/ilc/ ilc91/pdf/rep-v.pdf. Accessed 1 April 2021.

ILO (2006). The employment relationship. Report V(1). Paper presented at the International Labour Conference, $95^{\text {th }}$ Session, Geneva. http://www.ilo.org/public/english/standards/relm/ilc/ilc95/pdf/rep-v1.pdf. Accessed 1 April 2021.

Källner, E., \& Nyström, K. (2018). Entrepreneurial motivation and idea generation by displaced employees. International Review of Entrepreneurship, 16(3), 383-404.

Kautonen, T., \& Palmroos, J. (2010). The impact of a necessity-based start-up on subsequent entrepreneurial satisfaction. International Entrepreneurship and Management Journal, 6(3), 285-300. https://doi.org/10.1007/s11365-008-0104-1.

Lucas, R. E. (1978). On the size distribution of business firms. Bell Journal of Economics, 9(2), 508-523. https://doi.org/10.2307/3003596.

Millán, A., Millán, J. M., Román, C., \& Van Stel, A. (2013). How does employment protection legislation influence hiring and firing decisions by the smallest firms? Economics Letters, 121(3), 444448. https://doi.org/10.1016/j.econlet.2013.09.021.

Millán, J. M., Congregado, E., Román, C., Van Praag, M., \& Van Stel, A. (2014). The value of an educated population for an individual's entrepreneurship success. Journal of Business Venturing, 29(5), 612-632. https://doi.org/10.1016/j.jbusvent.2013.09.003.

Millán, A., Millán, J. M., \& Caçador-Rodrigues, L. (2020). Disclosing 'masked employees' in Europe: Job control, job demands and job outcomes of 'dependent self-employed workers'. Small Business Economics, 55(2), 461-474. https://doi.org/10.1007/s11187-019-00245-7.

Millán, J. M., Lyalkov, S., Burke, A., Millán, A., \& Van Stel, A. (2021). 'Digital divide' among European entrepreneurs: Which types benefit most from ICT implementation? Journal of Business Research, 125, 533-547. https://doi.org/10.1016/j.jbusres.2019.10.034.

Muehlberger, U. (2007). Dependent self-employment. Workers on the border between employment and self-employment. Palgrave Macmillan.

Muehlberger, U., \& Bertolini, S. (2008). The organizational governance of work relationships between employment and self-employment. Socio-Economic Review, 6(3), 449-472. https://doi.org/10.1093/ ser/mwm026.

Mühlböck, M., Warmuth, J. R., Holienka, M., \& Kittel, B. (2018). Desperate entrepreneurs: no opportunities, no skills. International Entrepreneurship and Management Journal, 14(4), 975-997. https:// doi.org/10.1007/s11365-017-0472-5.

OECD (2000). The employment outlook, chapter 5. OECD. http://www.oecd.org/els/emp/2079593.pdf. Accessed 1 April 2021.

OECD. (2014). The employment outlook, chapter 4. OECD. https://doi.org/10.1787/empl_outlook-2014-en.

Parker, S. C. (2018). The economics of entrepreneurship. Cambridge University Press. https://doi.org/10. $1017 / 9781316756706$.

Politis, D. (2005). The process of entrepreneurial learning: A conceptual framework. Entrepreneurship Theory and Practice, 29(4), 399-424. https://doi.org/10.1111/j.1540-6520.2005.00091.x.

Quinlan, M. (2012). The 'pre-invention' of precarious employment: The changing world of work in context. The Economic and Labour Relations Review, 23(4), 3-24. https://doi.org/10.1177/103530461202300402.

Quinlan, M., \& Johnstone, R. (2009). The implications of de-collectivist industrial relations laws and associated developments for worker health and safety in Australia, 1996-2007. Industrial Relations Journal, 40(5), 426-443. https://doi.org/10.1111/j.1468-2338.2009.00536.x.

Raffiee, J., \& Feng, J. (2014). Should I quit my day job?: A hybrid path to entrepreneurship. Academy of Management Journal, 57(4), 936-963. https://doi.org/10.5465/amj.2012.0522.

Reynolds, P., Camp, S. M., Bygrave, W. D., Autio, E., \& Hay, M. (2002). Global Entrepreneurship Monitor 2001 Executive Report. Babson College and London Business School. http://unpan1.un.org/intradoc/ groups/public/documents/un/unpan002481.pdf. Accessed 1 April 2021. 
Román, C., Congregado, E., \& Millán, J. M. (2011). Dependent self-employment as a way to evade employment protection legislation. Small Business Economics, 37(3), 363-392. https://doi.org/10. 1007/s11187-009-9241-3.

Román, C., Congregado, E., \& Millán, J. M. (2013). Start-up incentives: Entrepreneurship policy or active labour market programme? Journal of Business Venturing, 28(1), 151-175. https://doi.org/10. 1016/j.jbusvent.2012.01.004.

Rosen, S. (1981). The economics of superstars. American Economic Review, 71(5), 845-858 https:// www.jstor.org/stable/1803469.

Shepherd, D. A., \& DeTienne, D. R. (2005). Prior knowledge, potential financial reward, and opportunity identification. Entrepreneurship Theory and Practice, 29(1), 91-112. https://doi.org/10.1111/j. 1540-6520.2005.00071.x.

Sorgner, A., Fritsch, M., \& Kritikos, A. (2017). Do entrepreneurs really earn less? Small Business Economics, 49(2), 251-272. https://doi.org/10.1007/s11187-017-9874-6.

Stewart, A., \& Stanford, J. (2017). Regulating work in the gig economy: What are the options? The Economic and Labour Relations Review, 28(3), 420-437. https://doi.org/10.1177/1035304617722461.

Supiot, A. (2001). Beyond employment. Changes in work and the future of labour law in europe. Oxford University Press.

Tobin, J. (1958). Estimation of relationships for limited dependent variables. Econometrica, 26(1), 24-36. https://doi.org/10.2307/1907382.

Urbano, D., Audretsch, D. B., Aparicio, S., \& Noguera, M. (2020). Does entrepreneurial activity matter for economic growth in developing countries? The role of the institutional environment. International Entrepreneurship and Management Journal, 16(3), 1065-1099. https://doi.org/10.1007/ s11365-019-00621-5.

Van Stel, A., Millán, A., Millán, J. M., \& Román, C. (2018). The relationship between start-up motive and earnings over the course of the entrepreneur's business tenure. Journal of Evolutionary Economics, 28(1), 103-123. https://doi.org/10.1007/s00191-017-0499-3.

Wennekers, S., \& Van Stel, A. (2017). Types and roles of productive entrepreneurship: A conceptual study. In G. Ahmetoglu, T. Chamorro-Premuzic, B. Klinger, \& T. Karcisky (Eds.), The Wiley handbook of entrepreneurship (pp. 37-69). John Wiley \& Sons Ltd. https://doi.org/10.1002/9781118970812.ch3.

Williams, C. C. (2009). The motives of off-the-books entrepreneurs: Necessity-or opportunity-driven? International Entrepreneurship and Management Journal, 5(2), 203-217. https://doi.org/10.1007/ s11365-008-0098-8.

Williams, C. C., \& Horodnic, I. A. (2019). Dependent self-employment: Theory, practice and policy. Edward Elgar Publishing.

Williams, C., \& Lapeyre, F. (2017), Dependent self-employment: Trends, challenges and policy responses in the EU, ILO Employment Working Paper no. 228. Geneva: ILO. Available from: https://papers. ssrn.com/sol3/papers.cfm?abstract_id=3082819. Accessed 1 April 2021.

Publisher's note Springer Nature remains neutral with regard to jurisdictional claims in published maps and institutional affiliations. 


\section{Authors and Affiliations}

\section{André van Stel ${ }^{1,2} \mathbb{( D}$. Jorge Barrientos-Marín ${ }^{3}(\mathbb{D}) \cdot$ Leonel Caçador-Rodrigues $^{4} \mathbb{D}$. Ana Millán ${ }^{5}$. José María Millán ${ }^{6,7}$}

André van Stel

vanstela@tcd.ie

Jorge Barrientos-Marín

jorge.barrientos@udea.edu.co

Leonel Caçador-Rodrigues

leonel.rodrigues.uhu@gmail.com

Ana Millán

amillan@upo.es

1 Trinity Business School, Trinity College Dublin, Dublin, Ireland

2 Center for Entrepreneurship, Kozminski University, Warsaw, Poland

3 Department of Economics, University of Antioquia, Medellín, Colombia

4 International University of Andalusia, Santa María de la Rábida Campus, Huelva, Spain

5 Department of Financial Economics and Accounting, Pablo de Olavide University, Sevilla, Spain

6 Department of Economics, University of Huelva, Huelva, Spain

7 Facultad de Ciencias Empresariales y Turismo. Campus de "La Merced", Universidad de Huelva, Plaza de la Merced 11, 21002 Huelva, Spain 